\title{
Heat Pump Water Heater Ducting Strategies with Encapsulated Attics in Climate Zones 2 and 4
}

M. L. Sweet, A. Francisco, and S. G. Roberts Partnership for Home Innovation 


\section{NOTICE}

This report was prepared as an account of work sponsored by an agency of the United States government. Neither the United States government nor any agency thereof, nor any of their employees, subcontractors, or affiliated partners makes any warranty, express or implied, or assumes any legal liability or responsibility for the accuracy, completeness, or usefulness of any information, apparatus, product, or process disclosed, or represents that its use would not infringe privately owned rights. Reference herein to any specific commercial product, process, or service by trade name, trademark, manufacturer, or otherwise does not necessarily constitute or imply its endorsement, recommendation, or favoring by the United States government or any agency thereof. The views and opinions of authors expressed herein do not necessarily state or reflect those of the United States government or any agency thereof.

Available electronically at SciTech Connect http:/www.osti.gov/scitech

Available for a processing fee to U.S. Department of Energy and its contractors, in paper, from:

U.S. Department of Energy

Office of Scientific and Technical Information

P.O. Box 62

Oak Ridge, TN 37831-0062

OSTI http://www.osti.gov

Phone: 865.576.8401

Fax: 865.576.5728

Email: reports@osti.gov

Available for sale to the public, in paper, from:

U.S. Department of Commerce

National Technical Information Service

5301 Shawnee Road

Alexandria, VA 22312

NTIS http://www.ntis.gov

Phone: 800.553 .6847 or 703.605 .6000

Fax: 703.605.6900

Email: orders@ntis.gov 


\title{
Heat Pump Water Heater Ducting Strategies with Encapsulated Attics in Zones 2 and 4
}

\author{
Prepared for: \\ The National Renewable Energy Laboratory \\ On behalf of the U.S. Department of Energy's Building America Program \\ Office of Energy Efficiency and Renewable Energy \\ 15013 Denver West Parkway \\ Golden, CO 80401 \\ NREL Contract No. DE-AC36-08GO28308 \\ Prepared by: \\ M.L. Sweet, A. Francisco, and S.G. Roberts \\ Southface Energy Institute \\ As a part of the Home Innovations Research Lab's \\ Partnership for Home Innovation \\ 400 Prince George's Boulevard \\ Upper Marlboro, MD 20774 \\ NREL Technical Monitor: Stacey Rothgeb \\ Prepared under Subcontract No. KNDJ-0-40335-05
}

May 2016 
The work presented in this report does not represent performance of any product relative to regulated minimum efficiency requirements.

The laboratory and/or field sites used for this work are not certified rating test facilities. The conditions and methods under which products were characterized for this work differ from standard rating conditions, as described.

Because the methods and conditions differ, the reported results are not comparable to rated product performance and should only be used to estimate performance under the measured conditions. 


\section{Contents}

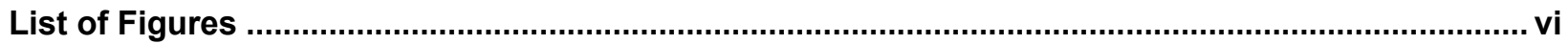

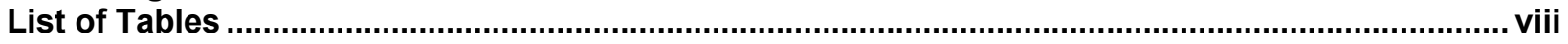

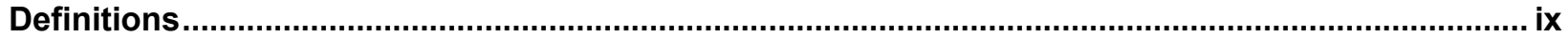

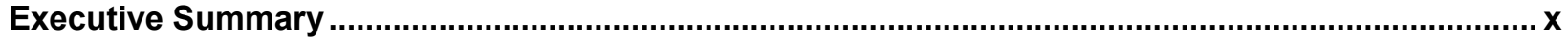

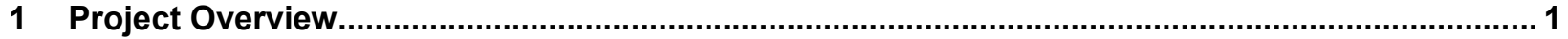

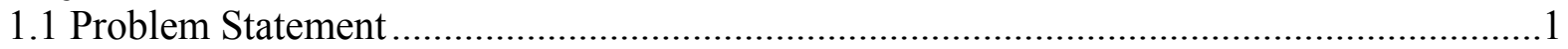

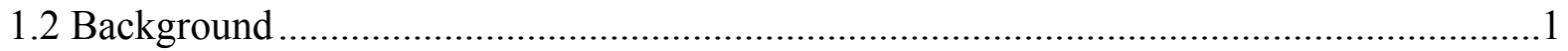

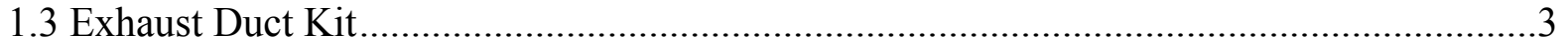

1.4 Introduction to Project Sites................................................................................

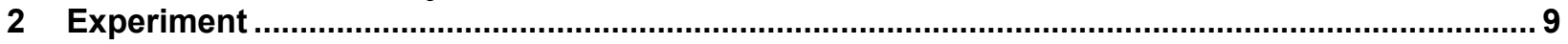

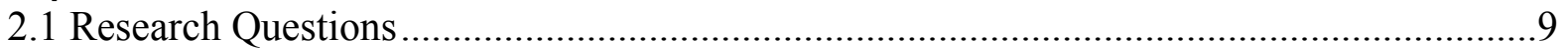

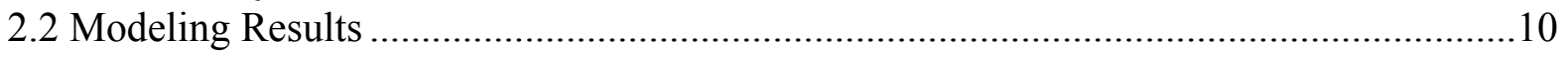

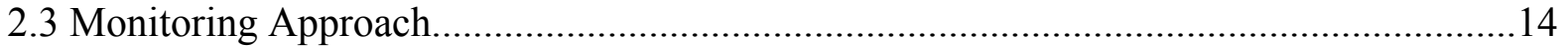

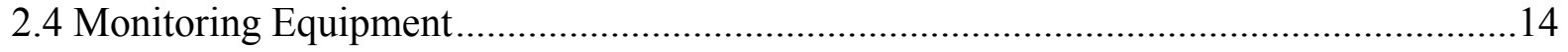

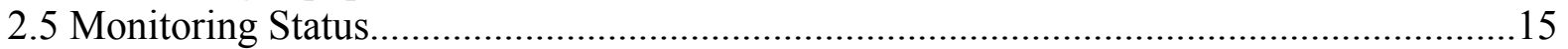

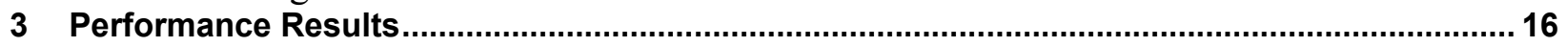

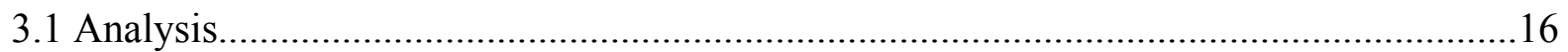

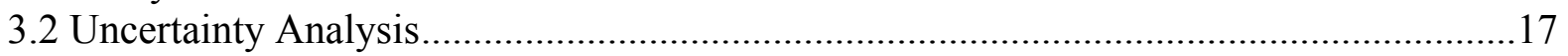

3.3 Comparison of Set Point Temperatures ...................................................................... 17

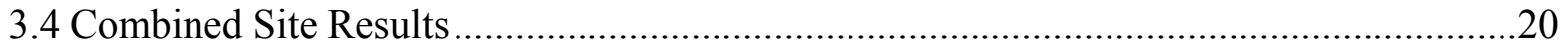

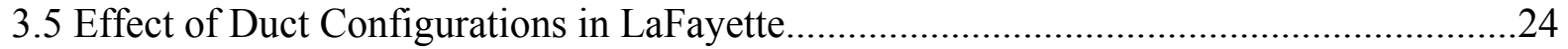

3.6 Impact on Encapsulated Attic Air Temperature and Humidity .....................................27

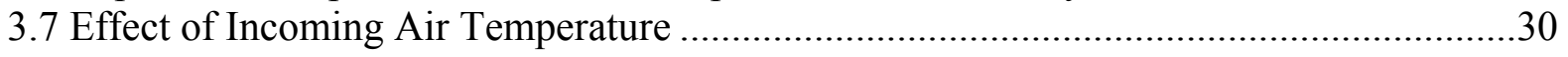

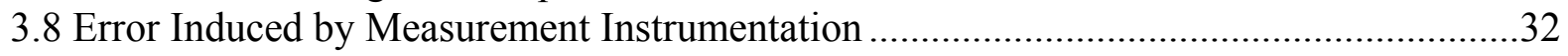

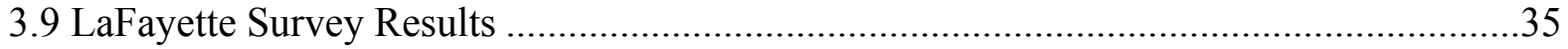

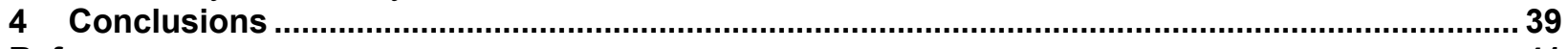

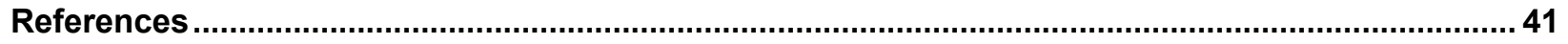




\section{List of Figures}

Figure 1. Exhaust duct kit supplied by A.O. Smith..................................................................... 4

Figure 2. Typical three-bedroom/two-bedroom duplex floor plan with red circles showing the locations of the HPWHs

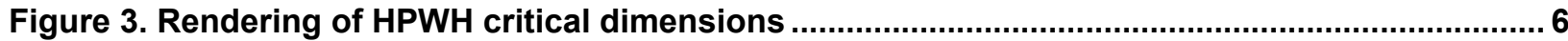

Figure 4. Vertical intake transfer duct leads to a vent in the mechanical closet's ceiling (left); horizontal exhaust duct connected to 3-in. $\times$ 14-in. rectangular duct inside the wall cavity leading to the HPWH in closet (right) .

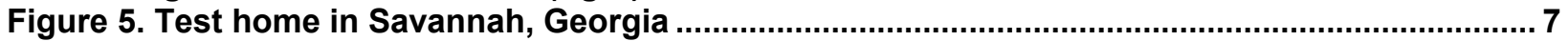

Figure 6. HPWH in encapsulated attic (left); unducted exhaust with 10 -ft duct attached (right) ....... 8

Figure 7. Site energy consumption of the typical two- and three-bedroom duplex units in

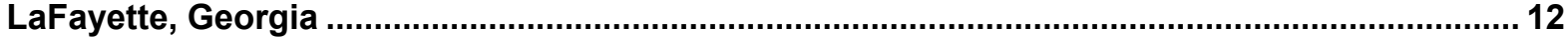

Figure 8. Site energy consumption of NCTH in Savannah, Georgia .............................................. 12

Figure 9. Monitoring equipment installed on the air intake side of the heat pump .......................... 15

Figure 10. Changes in the HPWH operating mode and tank set point temperature can be seen in the raw data

Figure 11. Processed data of daily HPWH incoming and outgoing water temperatures depicting a change in tank set point temperature. E1 includes period to the left of the first dashed line. E2 includes period to the right of the second dashed line.

Figure 12. Daily DHW use versus daily COP values for both set points at Savannah E ................... 20

Figure 13. Bar plot of daily COP values for Savannah showing large deviations across the monitored period

Figure 14. Bar plots of daily COP values of all four units in LaFayette. The bare areas indicate periods that did not meet all criteria to be considered valid data.............................................. 21

Figure 15. Scatter plot of daily DHW use versus COP for all five units ............................................22

Figure 16. Daily HPWH energy consumption as a function of daily DHW use and daily average $\Delta T$ across the tank

Figure 17. Intake air wet bulb temperature and daily average COP

Figure 18. Intake ducting installation at Site A duct kit installed on the intake side with temperature/RH sensor attached to the grille (left); insulated 8-in. flex duct connecting the duct to the attic (right)

Figure 19. Intake duct configuration at Site B. Transfer grille in the ceiling before being removed (left); ducted intake grille and sealed exhaust relief vent (right)

Figure 20. Relief vent grille supplied with the duct kits (left); flexible adhesive strip supplied by A.O. Smith to seal the relief vent (right)

Figure 21. Intake air temperature of Units $A, B$, and $C$ over the periods $T 1=8 / 26 / 14-9 / 16 / 14$ and $T 2$ $=9 / 18 / 14-10 / 19 / 14$. Units $A$ and $B$ had ducted intakes during T2 and Unit C's intake remained unducted for the entire period (+ indicate outliers).

Figure 22. Savannah E HPWH intake and exhaust temperatures and humidities........................... 28

Figure 23. Savannah Unit $E$ and $F$ absolute humidities at the high center location of the attic and of the living space.

Figure 24. Attic temperatures at five locations around the attic during the summer at Site $A$. The circled area can be seen in zoom in Figure 25. .

Figure 25. Zoomed section of Figure 24 showing attic temperature changes during HPWH operation

Figure 26. COP as a function of daily DHW consumption and intake air wet bulb temperature ....... 31

Figure 27. Brass fittings housing the thermocouples measuring outlet (left); inlet water temperatures and flow rate before being insulated (right)

Figure 28. Images of an insulated water meter and thermocouple brass fittings at the LaFayette site; front grille/filter showing obvious signs of debris (right) ................................................ 32

Figure 29. Effect of Badger Meter's thermal mass on water temperature measurements ................ 33

Figure 30. Histograms of daily average hot water temperatures measured leaving the tank during draw periods. Number of occurrences equals number of days.

Figure 31. Do you avoid taking consecutive showers to prevent running out of hot water?........... 35 
Figure 32. How often, if ever, do you experience a shortage of hot water while showering or bathing? ...................................................................................................................... 35

Figure 33. How often, if ever, do you experience a shortage of hot water while using the kitchen

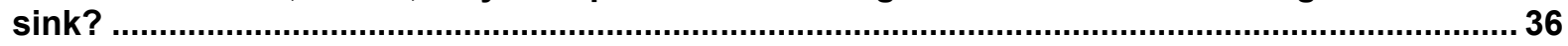

Figure 34. I am satisfied with the supply of hot water in my home. .............................................. 36

Figure 35. Do you hear noise from the mechanical equipment behind the locked doors in your

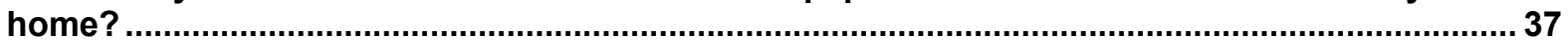

Figure 36. How often do you hear the operation of mechanical equipment behind the locked doors

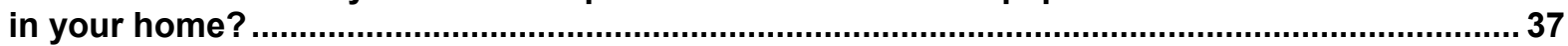

Figure 37. Does the noise disturb your daily activities? If yes, please explain. ............................... 38

Unless otherwise noted, all figures were created by Partnership for Home Innovation. 


\section{List of Tables}

Table 1. BEoptE+2.3 Inputs for Three Water Heater Types

Table 2. Model Site Energy Consumption (kWh/yr) and Change from an ERSWH to HPWH.

Negative Values Indicate a Net Gain from ERSWH

Table 3. Monitoring Equipment and Purpose............................................................................ 14

Table 4. Timeline of Monitoring Equipment and Dwelling Occupancy Activity. Units A, B, C, and D

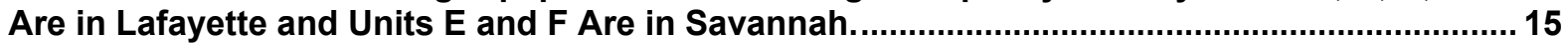

Table 5. Number of Monitored Days, Number of Occupants, and Average Daily DHW Use for Each

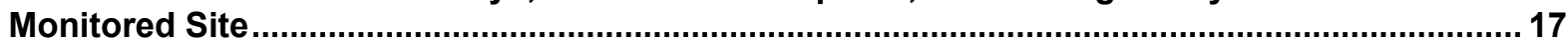

Table 6. Uncertainty for Example Daily Values ........................................................................... 17

Table 7. Unit E Time Frames of Differing Tank Set Points................................................................. 19

Table 8. Summary of All Monitored HPWH Daily Average Variables Used To Compute Daily Average COP.

Table 9. Date Ranges of Each Site and the Duct Configuration AppliedSite.

Table 10. Average Intake and Exhaust Air Temperatures and Absolute Humidities, Measured In Grains per Pound, across the Heat Pump during Operation ................................................... 31

Table 11. Statistics of Number of Occurrences of Short DHW Draw Durations .................................. 34

Unless otherwise noted, all tables were created by Partnership for Home Innovation. 


\section{Definitions}

$\begin{array}{ll}\text { BEopt }^{\mathrm{TM}} & \text { Building Energy Optimization Software } \\ \text { CFM } & \text { Cubic Feet per Minute } \\ \text { COP } & \text { Coefficient of Performance } \\ \text { CT } & \text { Circuit Transducer } \\ \text { ERSWH } & \text { Electric Resistance Storage Water Heater } \\ \text { DHW } & \text { Domestic Hot Water } \\ \text { GPM } & \text { Gallons per Minute } \\ \text { GPP } & \text { Grains per Pound } \\ \text { HPWH } & \text { Heat Pump Water Heater } \\ \text { HVAC } & \text { Heating, Ventilating, and Air Conditioning } \\ \text { IECC } & \text { International Energy Conservation Code } \\ \text { LHA } & \text { LaFayette Housing Authority } \\ \text { NCTH } & \text { New Construction Test Home } \\ \text { RH } & \text { Relative Humidity }\end{array}$




\section{Executive Summary}

This study focused on the performance of heat pump water heaters (HPWHs) with several duct configurations and their effects on whole-building heating, cooling, and moisture loads. A.O. Smith 60-gal Voltex (PHPT-60) HPWHs were included in the final designs at two project sites as an energy-conservation measure. The HPWHs were ducted to or installed within spray-foamencapsulated attics. A.O. Smith has been involved since the early stages of both projects, and its research and development team has provided insight and critical details.

The New Construction Test Homes (NCTHs) at both sites were completed in the beginning of 2013; however, they were not occupied until early 2014. The U.S. Department of Energy's Building America research team Partnership for Home Innovation partnered with Southface Energy Institute, the LaFayette Housing Authority, and the Housing Department of the City of Savannah to design energy-efficient, affordable housing for this study. LaFayette, Georgia, is situated in the northwestern corner of the state, approximately 30 miles due south of Chattanooga, Tennessee, in the mixed-humid climate (International Energy Conservation Code Climate Zone 4A). The LaFayette site consists of 30 units in 15 duplexes; each has an HPWH installed in the mechanical closet with exhaust ducts to the encapsulated attic and a transfer grille that allows supply air to enter the closet from the attic. The transfer grille and exhaust duct provide sufficient air volume to prevent the cooled air from recirculating.

For this study, the team monitored four NCTH units in two adjacent duplexes, each of which consisted of a two-bedroom unit $\left(1,040 \mathrm{ft}^{2}\right)$ and a three-bedroom unit $\left(1,245 \mathrm{ft}^{2}\right)$. Two singlefamily, one-story homes $\left(\sim 1,160 \mathrm{ft}^{2}\right)$ in Savannah, Georgia, were monitored. Savannah is located on the northern Georgia coast about 15 miles from the Atlantic Ocean in International Energy Conservation Code Climate Zone 2. The HPWH is installed in a spray-foam-encapsulated attic wherein a $10-\mathrm{ft}$ exhaust duct terminates. The exhaust duct was installed to determine its impact on HPWH performance and to prevent cooled air from recirculating. The house adjacent to the test home is of similar size, dimension, and construction, and the encapsulated attic includes an A.O. Smith electric resistance storage water heater (ERSWH). Attic temperature and relative humidity in this neighboring home were also monitored.

Building Energy Optimization E+2.3 models were constructed for the three-bedroom and twobedroom units of the typical duplexes in LaFayette and for the NCTH in Savannah. Duplex units in LaFayette have variable-speed, split-system, air-source heat pumps with a seasonal energyefficiency ratio of 14 and a heating season performance factor rating of 8 . The NCTH and neighboring unit in Savannah have ground-source heat pumps with a seasonal energy-efficiency ratio of 18.2 and a coefficient of performance of 3.7. Ducts for every monitored site are located in the encapsulated attics. Site energy use was analyzed for domestic hot water (DHW); cooling; heating; and a heating, ventilating, and air-conditioning (HVAC) fan/pump in each NCTH. DHW site energy consumption decreased significantly for the two- and three-bedroom units in LaFayette and the NCTH in Savannah by $1,287 \mathrm{kWh} / \mathrm{yr}(57 \%), 1,512 \mathrm{kWh} / \mathrm{yr}(56 \%)$, and 1,536 $\mathrm{kWh} / \mathrm{yr}(62 \%)$, respectively, compared to an ERSWH. The cooling site energy consumption of the three models decreased slightly by $59 \mathrm{kWh} / \mathrm{yr}(10 \%), 70 \mathrm{kWh} / \mathrm{yr}(9 \%)$, and $97 \mathrm{kWh} / \mathrm{yr}$ (11\%), respectively, which indicates that the cooling energy consumption decreased because the HPWH could cool and dehumidify air. The heating site energy consumption increased by 123 $\mathrm{kWh} / \mathrm{yr}(11 \%), 147 \mathrm{kWh} / \mathrm{yr}(11 \%)$, and $88 \mathrm{kWh} / \mathrm{yr}(11 \%)$, respectively, to compensate for the 
HPWH cooling air during the heating season. The models indicate that annual total home savings for an HPWH compared to an ERSWH was 1,222 kWh (28\%), 1,436 kWh (27\%), and 1,568 $\mathrm{kWh}(37 \%)$, respectively, which indicates an increase in savings with increased DHW consumption (because larger dwellings consume more DHW).

Ducted HPWH performance agreed with previous field studies of ducted and unducted HPWHs. The average water-heating coefficient of performance values ranged from 3.1 to 1.9 in heatpump-only mode. The survey results indicated overwhelming resident satisfaction with the DHW supply. The larger differences between incoming air temperature and humidity at Savannah compared to LaFayette reveal a linear relationship between incoming air temperature and HPWH performance. However, the smaller temperature and humidity differences between the four units in LaFayette revealed no discernable relationship. Other potential variables investigated for HPWH performance included inlet water temperature, number of heat pump operation events, total DHW demand, DHW demand during heat pump operation, and tank set point temperature. Ducting strategies such as exhaust duct only, intake duct only, and exhaust and intake ducting had no effect on HPWH performance vis-à-vis pressure drop across the heat exchange coils. However, the annual air temperature must be considered when the intake of an HPWH is being ducted.

The air conditioning provided by the HPWH affects only the temperature of the mechanical closet and attic space during the time the heat pump is operating. The HPWH's air-conditioning impact on HVAC equipment loads is minimal when the intake and exhaust airstreams are connected to a sealed attic and not to the living space. The zone temperatures return to their previous levels shortly after the HPWH stops operating. An HPWH was not suitable as a replacement dehumidifier in the sealed attics, because daily peak moisture loads were reduced only if the heat pump operated during the morning. Exhaust ducts should be insulated to avoid condensation on the exterior; however, this increases the risks of condensation inside the duct near the HPWH, which is caused by significant temperature variations between the compressor and the duct and bulk moisture around the condenser. All ducts should be at least 8 in. in diameter to prevent airflow restriction on A.O. Smith Voltex HPWHs. 


\section{Project Overview}

\subsection{Problem Statement}

This report presents the field-monitoring results of a ducted heat pump water heater (HPWH) study that includes five A.O. Smith Voltex HPWHs that were installed in two geographic locations in two climate zones. Both sites are affordable housing projects where Southface Energy Institute partnered with the local municipality's housing departments to improve building sustainability. The test plan was developed around the following research foci:

- Evaluate ducting strategies for HPWHs in test sites in two climate zones. A test site in LaFayette, Georgia (International Energy Conservation Code [IECC] Climate Zone 4A), includes HPWHs in mechanical closets inside the thermal envelope with ducting to an encapsulated attic. The test site in Savannah, Georgia (IECC Climate Zone 2A), includes an HPWH that is directly inside an encapsulated attic in which ducts terminate.

- Derive the coefficient of performance (COP) during real-world use patterns.

- Evaluate the HPWH's ability to satisfy domestic hot water (DHW) demand in the efficiency mode (heat pump only) with set points of $120^{\circ} \mathrm{F}$ and $150^{\circ} \mathrm{F}$ (due to an unexpected change in set point temperature at the Savannah site).

- Determine the impact of HPWH exhaust air on temperature and relative humidity (RH) conditions in mechanical closets and attic space. Temperature and RH of a single-family home with a HPWH in the sealed attic are compared to a nearly identical house with an electric resistance storage water heater (ERSWH) in the attic.

- Investigate the impacts of different HPWH ducting strategies on whole-house heating, cooling, and moisture loads.

- Evaluate the cost-effectiveness of the HPWH water-heating strategy, especially in the context of affordable and rental housing.

\subsection{Background}

HPWH technology was first patented in 1935 and commercialized in the 1950s, but the technology has recently been commercialized due to dramatically improved technology, economic viability, and the "green energy" movement (Shapiro and Puttagunta 2013). An HPWH uses an air-source heat pump as the main heat source and has electric resistance elements as auxiliary heaters. An HPWH also provides space cooling and dehumidification to its surroundings; it affects the heating, ventilating, and air-conditioning (HVAC) performance of the entire house if it is placed inside the conditioned space. The performance and side effects of HPWHs are dependent upon a number of variables, such as ambient air temperature, humidity, outgoing draw profile, and incoming water temperature. HPWHs have undergone extensive testing in laboratory settings to quantify their individual performance (Sparn et al. 2011).

An HPWH must be installed in a location with a certain volume of air to avoid recirculating cool exhaust air, which could reduce its efficiency. Historically, HPWH installation in conditioned spaces was challenging due to the confined spaces where electric or gas water heaters were often installed, such as closets and mechanical rooms. Duct kits enable HPWHs to be installed in small, confined spaces in new and existing buildings. They also present opportunities to move cooled and dehumidified air to optimize whole-house cooling and moisture loads, which reduce 
HVAC loads. Ducts can be configured such that cool, dehumidified air can be delivered to a living zone during the summer and exhausted to the outside during the winter. Sparn et al. (2013) proposed that ducts can also be configured to provide conditioned outdoor air in the living zone to minimize ventilation requirements. However, evaluation of ducted HPWH performance in real-world installations and their effects on home comfort, HVAC energy use, and controls is still in its infancy because data are lacking and few companies make it easy to duct HPWHs. Southface adhered to the National Renewable Energy Laboratory's Field Monitoring Protocol for HPWHs (Sparn et al. 2013) to collect valuable data about in-situ ducted HPWHs to add to the limited field-monitored data and serve as a reference point for the refinement of HPWH computational models.

The U.S. Department of Energy's Building America research team Partnership for Home Innovation analyzed five 60-gal A.O. Smith Voltex HPWHs (model PHPT-60) that were installed in home attics that were encapsulated with open-cell spray polyurethane foam rooflines. The HPWH units were designed to operate in four modes (which differ from newer Voltex models):

- Efficiency. The most energy-efficient mode. This mode uses the heat pump alone to heat the water in the tank. The electric resistance elements are not used unless the ambient operating temperature is lower than $45^{\circ} \mathrm{F}$ or higher than $109^{\circ} \mathrm{F}$ to prevent damage to the refrigerant cycle components. The heat pump turns on when the tank temperature drops $9^{\circ} \mathrm{F}$ lower than the set point. Tank temperature is calculated through a weighted average of the two thermistor readings at the upper and lower parts of the tank, in which the upper thermistor reading accounts for $75 \%$ of the weight (Sparn et al. 2011).

- Hybrid. This is the default, manufacturer-recommended setting. This mode uses the heat pump as the primary heating source. The upper heating element operates during large DHW draws when the average tank temperature drops $18^{\circ} \mathrm{F}$ lower than the set point.

- Electric. The water heater functions as a conventional electric unit and relies solely on the electric resistance elements to heat the water in the tank.

- Vacation. The controller adjusts the water temperature set point to $60^{\circ} \mathrm{F}$ and is recommended when no DHW draws are planned for a long period. This mode minimizes energy consumption and prevents the water heater from freezing during cold weather.

The efficiency mode was of primary interest in this study. The PHPT series can be ducted (maximum of $10 \mathrm{ft}$ ) to another zone when the free air volume of the occupied zone is lower than $750 \mathrm{ft}^{3}$ (A.O. Smith 2011b, 2012). Inlet and Outlet Duct Kits, which are identical, are available from the manufacturer and enable multiple ducting configurations.

Two notable laboratory analyses have been conducted on the 80-gal A.O. Smith Voltex HPWH (model PHPT-80) (Larson and Bedney 2011; Sparn et al. 2011). Larson and Bedney and Sparn et al. used the same data set for their independent analyses. The differences between the PHPT-80 and PHPT-60 are limited to the tank volume and anode size ( $2 \mathrm{~mm}$ for PHPT-60; $3 \mathrm{~mm}$ for PHPT-80), as stated by A.O. Smith's representative and literature (A.O. Smith 2011b). Across the studies, A.O. Smith 80-gal HPWHs had various draw profiles imposed under different conditions; the resulting COPs in efficiency mode ranged from 2.0 to 3.5 (Sparn et al. 2011) and in hybrid mode from 1.8 to 3.5 (Larson and Bedney 2011). None of the studies investigated the 
use of the manufacturer's optional duct kits; however, two studies investigated the effect on COP of reduced airflow over the heat pump's evaporation coil. Reducing airflow by blocking onethird of the intake grille caused an insignificant decrease $(<1 \%)$; a two-thirds blockage caused a decrease on COP values of $\sim 6 \%$ to $\sim 2 \%$ during the heating cycle (Sparn et al. 2011). The effect of ducting the HPWH was expected to be similar to the one-third blocked case due to the grille area blockage of the duct kits and the increased static pressure from the ducts.

Shapiro and Puttagunta (2013) conducted a Building America field-monitoring study on both the 60- and 80-gal A.O. Smith Voltex HPWHs and reported COP values of 2.1 for both model sizes. The 80 -gal unit did not use the electric resistance elements; $11 \%$ of the 60 -gal unit's energy consumption was from the electric resistance elements. They also reported an efficiency reduction of 16\% (COP 1.76) for installations in confined spaces. This study focuses on different duct configurations for HPWHs installed in confined spaces to determine the optimal configuration and potentially avoid such an efficiency reduction.

The Electric Power Research Institute also conducted field monitoring of more than 145 HPWHs; however, the results have been anonymized to hide model/manufacturer information. The COP calculations were also reported as weighted monthly averages; values ranged from 1.1 to 1.9 (Amarnath and Bush 2012). Ecotope and the Northwest Energy Efficiency Alliance (2015) studied 50 HPWHs in myriad conditions and reported that the average annual COP varied between 1.6 and 2.4. The results from this project will be compared to previous field-monitored studies vis-à-vis trends in operation and performance.

The HPWHs were installed at each site by local plumbing tradesmen whose HPWH training consisted of a 30-min installation video that was provided by A.O. Smith. The ducts were installed by local HVAC tradesmen and commissioned by Southface for an extra cost of $\$ 250$ $\$ 300 /$ unit at the LaFayette site. The only installation issue to date that was specific to HPWHs was that the plumber installed a condensation drainpipe in only one of the two condensation drains, which caused a leak into the drain pan.

\subsection{Exhaust Duct Kit}

The exhaust duct kit (Figure 1) supplied by the manufacturer was installed easily using a \#2 Phillips screwdriver, wire cutters (to cut the flex duct), and scissors. Once the kit was screwed to the heat pump, a short run of 8-in. flex duct connected the kit to the permanent metal duct in LaFayette. A.O. Smith exhaust duct kits have a relief vent below the round duct connection to prevent damage to the heat pump from excessive ducting pressure increases. This study investigated the relief vent's effects on intake air temperature and humidity and to determine if sealing the vent to force all the exhaust air to the attic had any impacts. Due to the size of the mechanical closets in LaFayette, operating the HPWHs completely unducted was against the manufacturer's recommendation and warranty. It was also not of interest because a previous Building America study reported a performance decrease of 16\% when installed in confined spaces, and preliminary results showed ducted HPWHs performed comparably to unducted HPWHs in field studies (Shapiro and Puttagunta 2013). 


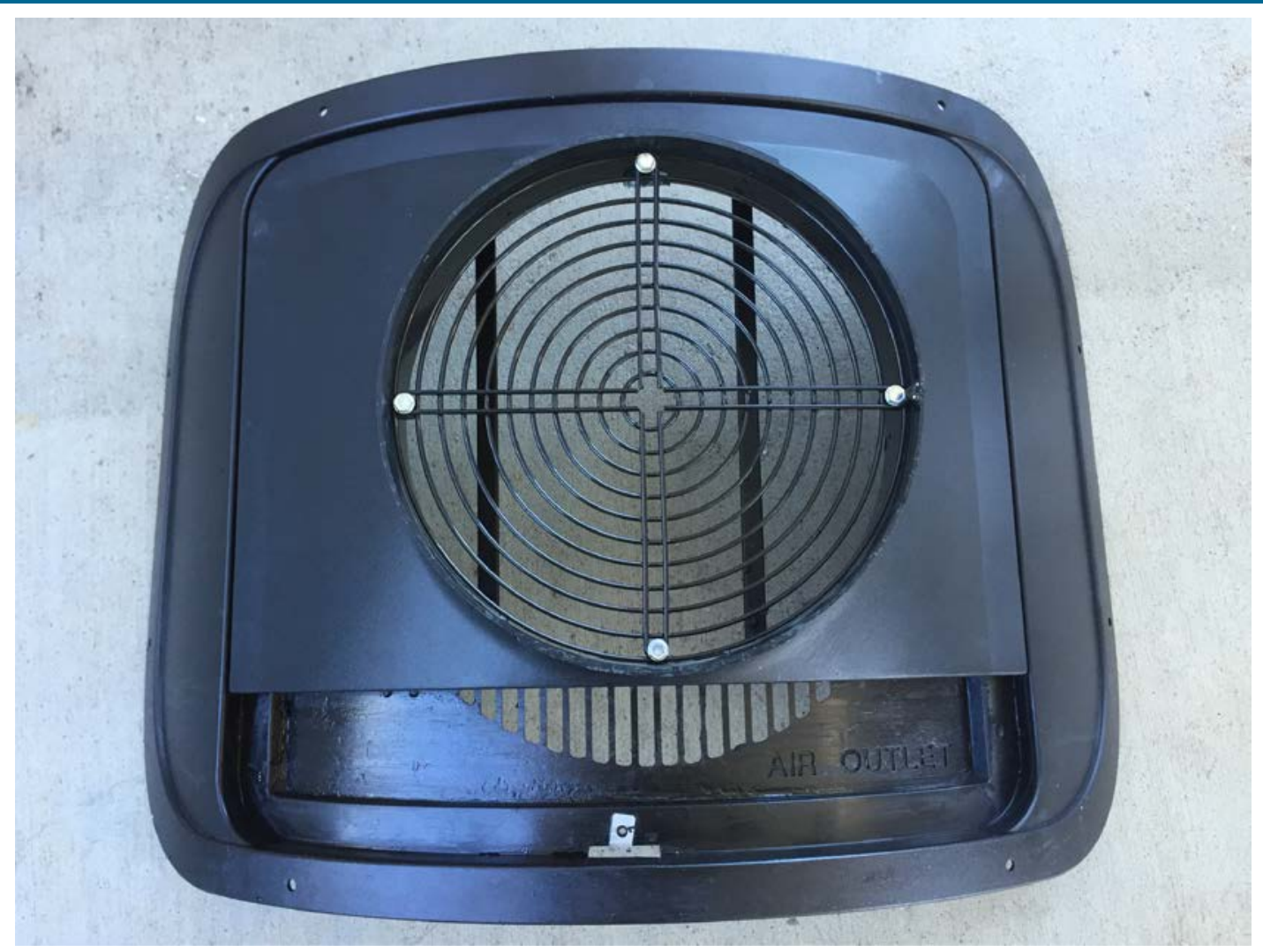

Figure 1. Exhaust duct kit supplied by A.O. Smith

\subsection{Introduction to Project Sites}

With the support of the U.S. Department of Energy's Building America program, Southface partnered with the LaFayette Housing Authority (LHA) and the Housing Department of the City of Savannah to assist with the design of energy-efficient residential dwellings in their respective locales. The all-electric New Construction Test Homes (NCTHs) at both sites were completed in the beginning of 2013; however, they were not occupied until early 2014. The LaFayette site has 30 60-gal A.O. Smith Voltex HPWHs; the Savannah site has one house with an HPWH installed. Each HPWH intakes and exhausts air from an open-cell, spray-polyurethane-foam-encapsulated attic. Bill Hosken, national sales manager for A.O. Smith, was involved since the early stages of both projects and provided insight and critical details from A.O. Smith's research and development team.

LHA hired the architecture firm Lord Aeck Sargent to design 30 sustainable and affordable housing units that sought Gold certification in Leadership in Energy \& Environmental Design in 15 duplexes. These units were built on two sites (1.3 geographic miles apart) in LaFayette, Georgia, that included 16 units ( 8 duplexes) at one site and 14 units ( 7 duplexes) at the other. LaFayette is situated in the northwestern corner of the state, approximately 30 miles due south of Chattanooga, Tennessee. Heating degree days (base 65) for this site are approximately 3,200, and cooling degree days are approximately 1,700 for the mixed-humid climate (IECC Climate Zone 4). Figure 2 shows the three-bedroom/two-bedroom floor plan of 14 duplex buildings; the $15^{\text {th }}$ building is a two-bedroom/two-bedroom duplex that is designed to meet Uniform Federal Accessibility Standards. Two buildings (four units) at the same location were chosen for long- 
term monitoring of HPWH variables of interest. Duplex units in LaFayette have variable-speed, split-system, air-source heat pumps with a seasonal energy-efficiency ratio of 14 and a heating season performance factor rating of 8 .

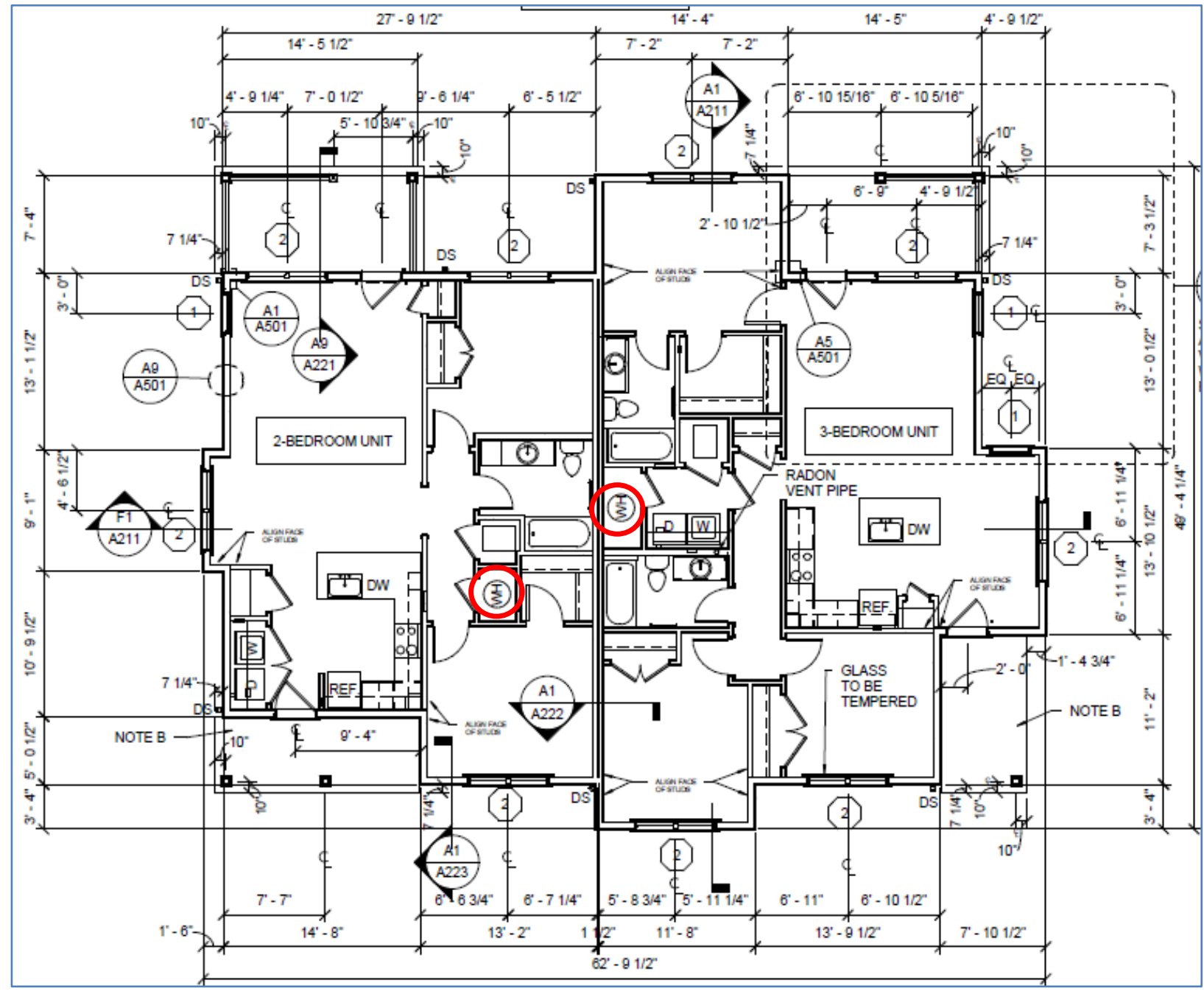

Figure 2. Typical three-bedroom/two-bedroom duplex floor plan with red circles showing the locations of the HPWHs

The HPWHs in LaFayette were installed in the mechanical closets with doorways that were fitted with a door shoe to reduce noise and air transfer to the living space. Noise reduction was the primary reason to duct the HPWHs to the attic and not use a louvered door, because previous studies have reported noise as the major complaint from tenants who live with HPWHs (Chasar and Martin 2013). Figure 3 shows a schematic of the ducted HPWH installation in the mechanical closet. The ceiling of the mechanical closet has a transfer duct to the encapsulated attic to provide intake air (Figure 4, left); the HPWH's exhaust is directly ducted to the attic (Figure 4, right). The distance between the ducts' terminals is to be a minimum of $5 \mathrm{ft}$, and the different orientations of the ducts are to prevent cool exhaust air from recirculating into the intake duct. 


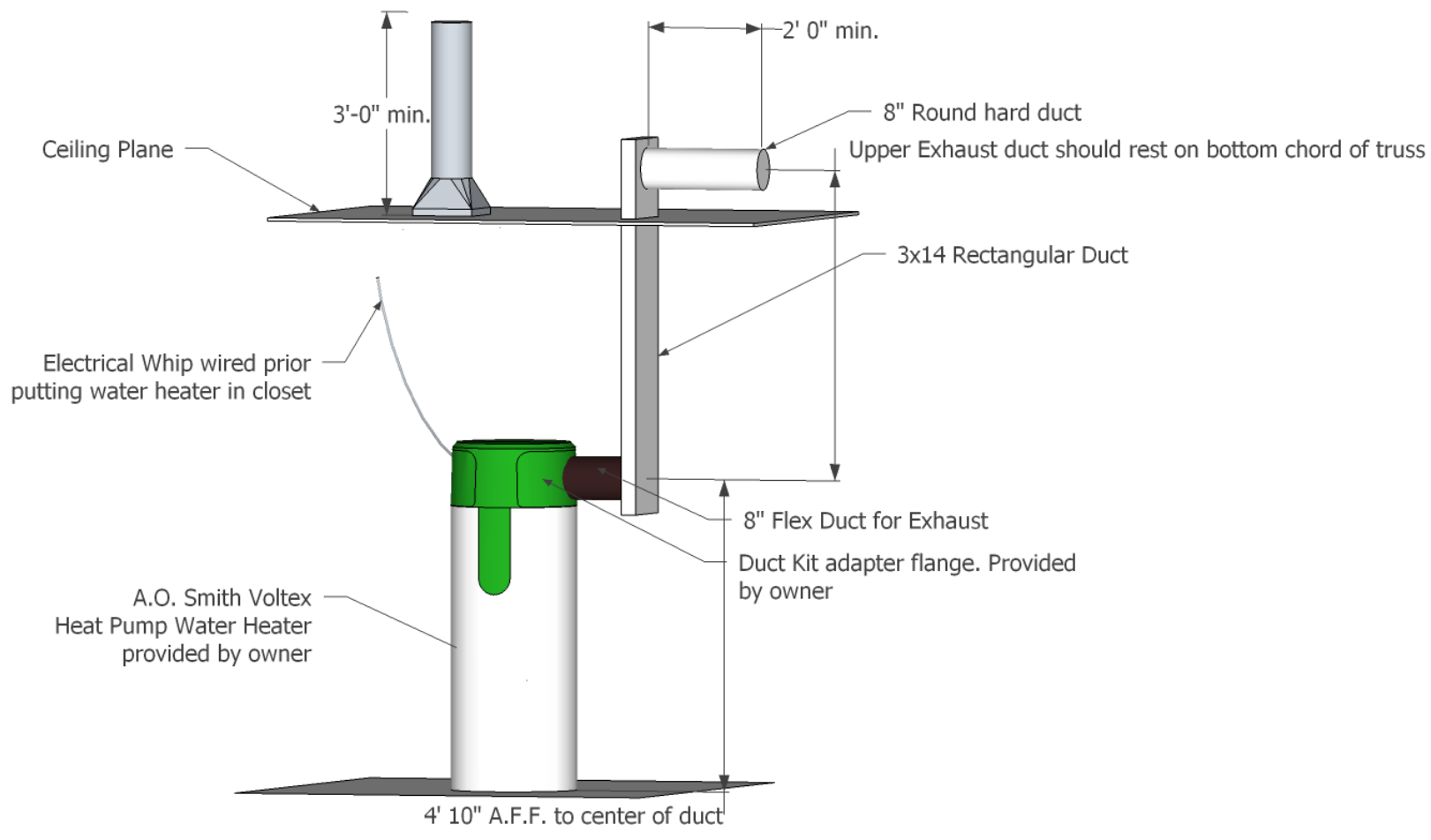

Figure 3. Rendering of HPWH critical dimensions
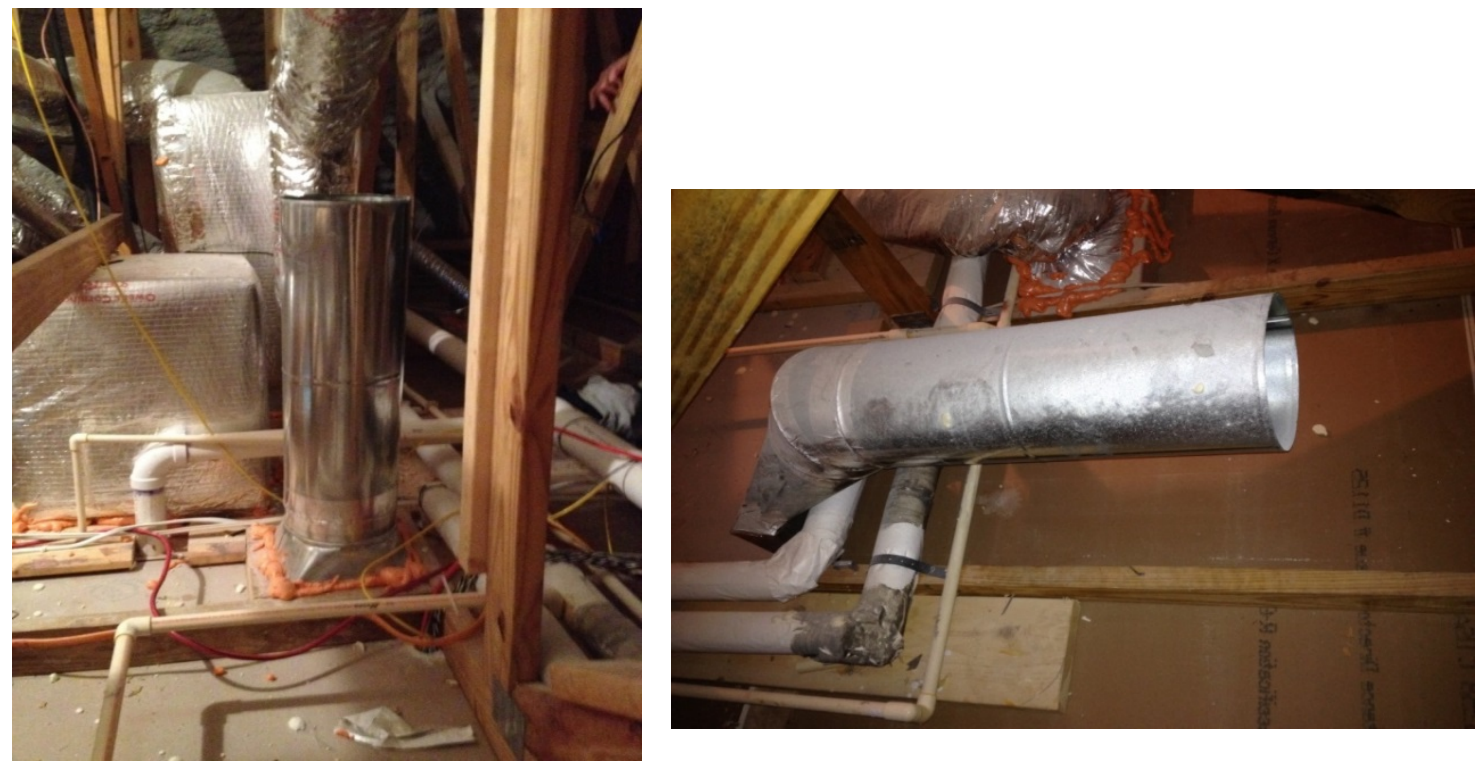

Figure 4. Vertical intake transfer duct leads to a vent in the mechanical closet's ceiling (left); horizontal exhaust duct connected to 3 -in. $\times 14$-in. rectangular duct inside the wall cavity leading to the HPWH in closet (right) 
The test home (Figure 5) in Savannah, Georgia, is located in the Savannah Gardens community, a 44-acre site that was developed to meet the standards of the EarthCraft Communities ${ }^{1}$ program (Community Housing Services Agency Inc. 2012). Heating degree days (base 65) for this site are approximately 1,700 , and cooling degree days are approximately 2,500 . The site is near the northern boundary of IECC Climate Zone 2. The three-bedroom, two-bathroom, all-electric test home has approximately $1,200 \mathrm{ft}^{2}$ of conditioned space on an elevated slab foundation. The HPWH is installed in a spray-foam-encapsulated attic $\left(\sim 1,508 \mathrm{ft}^{3}\right)$ wherein a 10 - $\mathrm{ft}$ duct terminates (Figure 6) to prevent air recirculation and provide insight about attic air conditions when ducted. The house adjacent to the test home is of similar size, dimension, and construction with an electric 50-gal A.O. Smith water heater (ECRT-52) in its encapsulated attic. The temperature and $\mathrm{RH}$ in the attic of this neighboring home were also monitored. The NCTH and neighboring home have ground-source heat pumps with a seasonal energy-efficiency ratio of 18.2 and COP of 3.7. HVAC ducts for every monitored site are located in encapsulated attics.

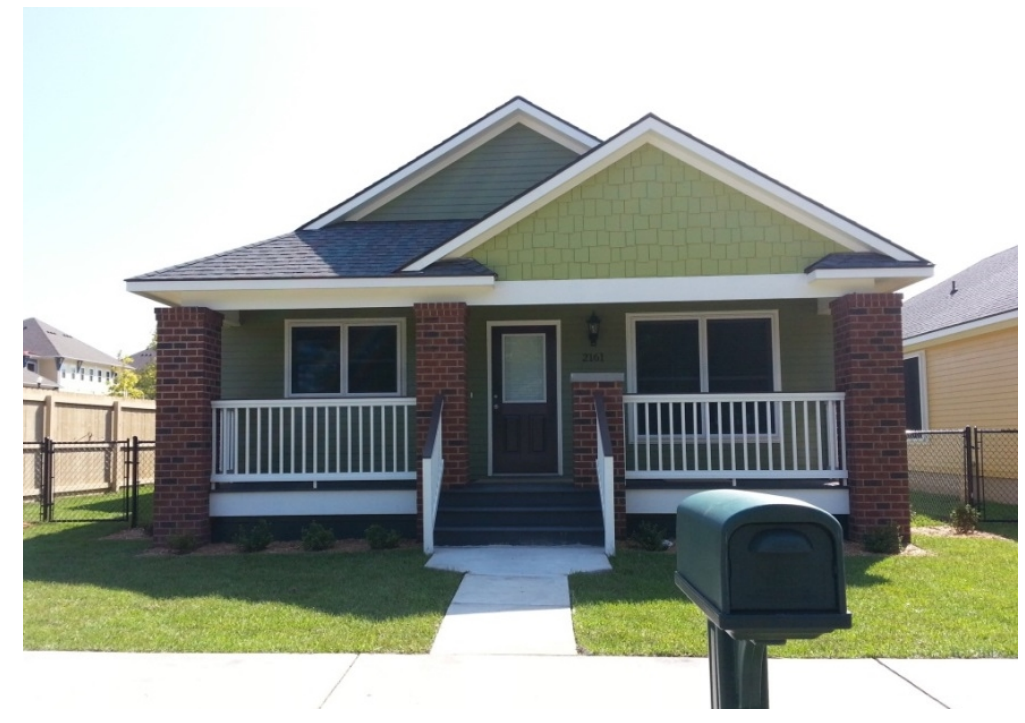

Figure 5. Test home in Savannah, Georgia

\footnotetext{
${ }^{1}$ http://www.earthcraft.org/builders/programs/earthcraft-communities/
} 


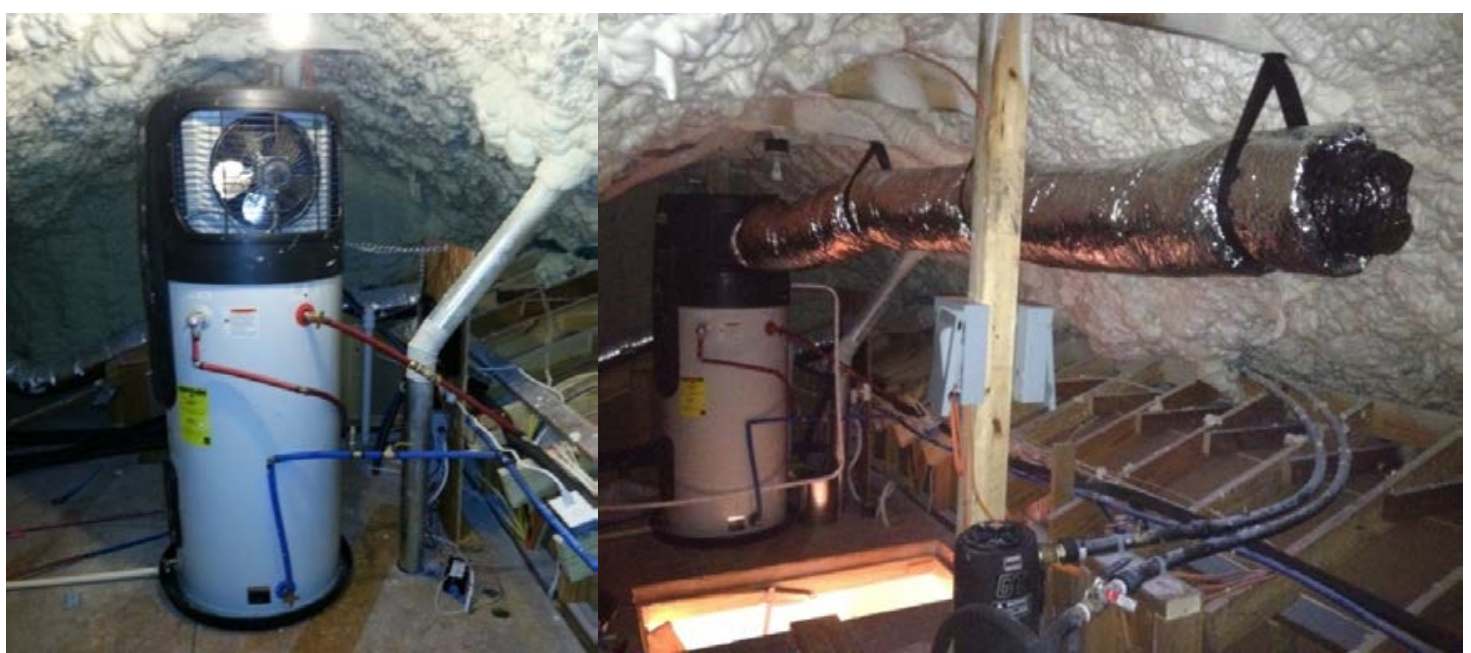

Figure 6. HPWH in encapsulated attic (left); unducted exhaust with 10-ft duct attached (right) 


\section{Experiment}

\subsection{Research Questions}

The following research questions/hypotheses were developed from the aforementioned research foci and are answered in Section 4:

- Do HPWHs installed in or connected to encapsulated attics perform differently in different climate zones?

Exterior conditions in IECC Climate Zone 2 are warmer and more humid annually than in IECC Climate Zone 4. It is not clear how these exterior conditions, attic-to-living-zone connectivity, and thermostat set points impact attic air temperatures and humidities in the two climates, which are determinants of HPWH COP.

- How do the real-world COPs vary when they are subjected to different use patterns, and how do they compare to other field studies?

Real-world COPs are expected to vary depending on average tank temperature, ambient air temperature and humidity, local incoming water temperature, and water draw patterns. Long-term average real-world COPs are expected to be similar to laboratory results under similar conditions.

- Did the HPWH satisfy DHW demand in the efficiency operating mode?

The HPWH is expected to satisfy DHW demand in efficiency mode most of the time. To prevent the equipment from abuse, tenants of the duplexes in LaFayette do not have access to the HPWHs to change their operation or tank set points. A survey will be conducted of the residents of all 30 duplex units to document their satisfaction with their DHW supply. Power data of the HPWH in Savannah will reveal any changes to mode of operation.

- How much does HPWH exhaust air affect temperature and RH conditions in the mechanical closet and attic space compared to alternative systems?

The exhaust/input air will affect temperature and $\mathrm{RH}$ conditions in any zone it draws or exhausts air to or from. Small mechanical closets are expected to experience greater temperature and $\mathrm{RH}$ variances during heat pump operation; these variances in attics are expected to be localized to the area of air exchange. Variations in closets are expected to influence COP values when the intake is not directly ducted.

- Do different HPWH ducting strategies affect whole-house heating, cooling, and moisture loads?

The HPWH installed in the encapsulated attic in Savannah is expected to reduce cooling and moisture loads compared to the similar neighboring home with an ERSWH in the encapsulated attic. Different duct strategies in LaFayette will have the greatest effect on attic air conditions. The whole-house heating, cooling, and moisture loads will vary depending on the area of air pathways between the attic and conditioned space. Different duct strategies will also directly influence COP values.

- How well does Building Energy Optimiztion (BEopt $\left.{ }^{\mathrm{TM}}\right)$ software account for the interaction of the HPWH and total space heating, cooling, and moisture loads? 
Ducting air to or from the encapsulated attic will lower the average annual attic temperature and provide dehumidification relief during the summer. HPWH operation is expected to decrease annual HVAC load in the hot-humid climate of Savannah. The impact on the HVAC load in LaFayette is expected to be less significant — and likely negligible - because it has fewer cooling degree days than Savannah.

\subsection{Modeling Results}

BEopt E+2.3 models were constructed for the NCTH in Savannah, and of the three-bedroom and two-bedroom units of the typical duplexes in LaFayette, in accordance with the National Renewable Energy Laboratory's Building America House Simulation Protocols (Engebrecht Metzger et al. 2012; Hendron and Engebrecht, 2010; Wilson et al. 2013). Each model was simulated with an ERSWH, HPWH, and a typical electric tankless water heater. The default specifications in BEopt were used for the ERSWH and tankless water heater; the HPWH specifications were from A.O. Smith's documentation of its 60-gal Voltex (PHPT-60). In all cases, the water heaters were modeled as installed inside the sealed unfinished attic space, because BEopt cannot model the ducted case yet the HPWHs exchange air with the attics and not the living zones. All input specifications are listed in Table 1.

The site energy use was analyzed because these units are all-electric. Site energy for HVAC fan/pump, cooling, heating, and DHW is shown in Figure 7, Figure 8, and Table 2. The total values do not include energy loads from miscellaneous, ventilation fan, large appliances, or lights, because these values were not impacted by the water heater. The DHW site energy consumption decreased significantly for the two-bedroom and three-bedroom units in LaFayette and the NCTH in Savannah by 1,287 kWh/yr (57\%), 1,512 kWh/yr (56\%), and 1,536 kWh/yr (62\%), respectively, compared to the ERSWH. The cooling site energy consumption of the three models decreased slightly by $59 \mathrm{kWh} / \mathrm{yr}(10 \%), 70 \mathrm{kWh} / \mathrm{yr}(9 \%)$, and $97 \mathrm{kWh} / \mathrm{yr}(11 \%)$, respectively, which indicates cooling energy consumption decreased because the HPWH could cool and dehumidify air. The heating site energy consumption increased by $123 \mathrm{kWh} / \mathrm{yr}(11 \%)$, $147 \mathrm{kWh} / \mathrm{yr}(11 \%)$, and $88 \mathrm{kWh} / \mathrm{yr}(11 \%)$, respectively, to compensate for the HPWH cooling air during the heating season. The HVAC fan/pump energy consumption stayed the same for both LaFayette models, but it decreased by $23 \mathrm{kWh} / \mathrm{yr}(6 \%)$ in Savannah, likely due to the ground-source heat pump. The models indicate the HPWH has net space-conditioning penalties in LaFayette of $64 \mathrm{kWh} / \mathrm{yr}$ and $77 \mathrm{kWh} / \mathrm{yr}$, respectively. The HPWH had a net spaceconditioning decrease in Savannah of $9 \mathrm{kWh} / \mathrm{yr}$, because it is a predominantly cooling climate (Climate Zone 2). An electric tankless water heater was also modeled in each dwelling. The tankless water heater reduced DHW site energy consumption marginally from the ERSWH models by $8 \%, 6 \%$, and $6 \%$, respectively, and consumed more than 3 times the energy as the HPWHs. The tankless water heater decreased the space-conditioning load by $26 \mathrm{kWh} / \mathrm{yr}$ and 24 $\mathrm{kWh} / \mathrm{yr}$ in LaFayette and increased the load by $5 \mathrm{kWh}$ in Savannah.

The models show the annual total home savings for a HPWH compared to an ERSWH was 1,222 $\mathrm{kWh}(28 \%), 1,436 \mathrm{kWh}(27 \%)$, and 1,568 kWh (37\%), respectively, which indicates an increase in savings with increased DHW consumption (because larger dwellings consume more DHW). With an average electricity cost of $\$ 0.11 / \mathrm{kWh}^{2}$, HPWHs can save $\$ 134$ to $\$ 172 / \mathrm{yr}$ compared to

\footnotetext{
${ }^{2}$ According to the U.S. Energy Information Administration's 2015 year-to-date residential electricity cost data for Georgia.
} 
an ERSWH. The National Appliance Energy Conservation Act increased the efficiency requirements of electric water heaters in April 2015. Tank volumes greater than 50 gal must now meet efficiency standards that are achieved only by HPWHs. A 60-gal HPWH would cost \$2,100 to purchase and install ducts; two 30-gal ERSWH would cost $\$ 500$. However, the confined spaces in LaFayette would not have enough area to install two 30-gal tanks side by side, so a shelf would have to be installed at additional cost. The HPWH would have a simple payback period of 9.3-11.9 years, which is within the useful life expectancy.

Table 1. BEoptE+2.3 Inputs for Three Water Heater Types

\begin{tabular}{|c|c|c|}
\hline & & Units \\
\hline \multicolumn{3}{|c|}{ HPWH Inputs } \\
\hline Volume & 60 & Gal \\
\hline Input-Electric & 0 in HP mode 4.5 in hybrid & $\mathrm{kW}$ \\
\hline Location & Unfinished attic & \\
\hline Set Point & 120 & ${ }^{\circ} \mathrm{F}$ \\
\hline HPWH Minimum Ambient Temperature & 45 & ${ }^{\circ} \mathrm{F}$ \\
\hline HPWH Maximum Ambient Temperature & 109 & ${ }^{\circ} \mathrm{F}$ \\
\hline HPWH Compressor Input & 850 & W \\
\hline HPWH COP & $2.34^{\mathrm{a}}$ & \\
\hline HPWH SHR & 0.88 & \\
\hline HPWH Airflow Rate & 475 & $\mathrm{cfm}$ \\
\hline HPWH Fan Power & 0.17 & W/cfm \\
\hline HPWH Parasitics & 8 & W \\
\hline HPWH Tank UA & 3.7 & Btu/h-R \\
\hline HPWH Recovers with Element & True & \\
\hline HPWH Simultaneous Element & False & \\
\hline \multicolumn{3}{|c|}{ Tank Electric Inputs } \\
\hline Volume & 60 & Gal \\
\hline Rated Energy Factor & 0.92 & $\mathrm{EF}$ \\
\hline Installed Energy Factor & 0.92 & $\mathrm{EF}$ \\
\hline Input-Electric & 4.5 & $\mathrm{~kW}$ \\
\hline Location & Living space & \\
\hline Set Point & 120 & ${ }^{\circ} \mathrm{F}$ \\
\hline \multicolumn{3}{|c|}{ Tankless Electric Inputs } \\
\hline Rated Energy Factor & 0.99 & $\mathrm{EF}$ \\
\hline Installed Energy Factor & 0.99 & $\mathrm{EF}$ \\
\hline Cycling Derate & 0.08 & Fraction \\
\hline Input-Electric & $100,000,000^{\mathrm{b}}$ & $\mathrm{kW}$ \\
\hline Location & Living space & \\
\hline Set Point & 120 & ${ }^{\circ} \mathrm{F}$ \\
\hline
\end{tabular}

${ }^{a}$ Average measured COP value from all sites combined.

${ }^{\mathrm{b}}$ Default value is unrealistic, but adjusting the value to $18 \mathrm{~kW}$ had no effect on the outputs. 


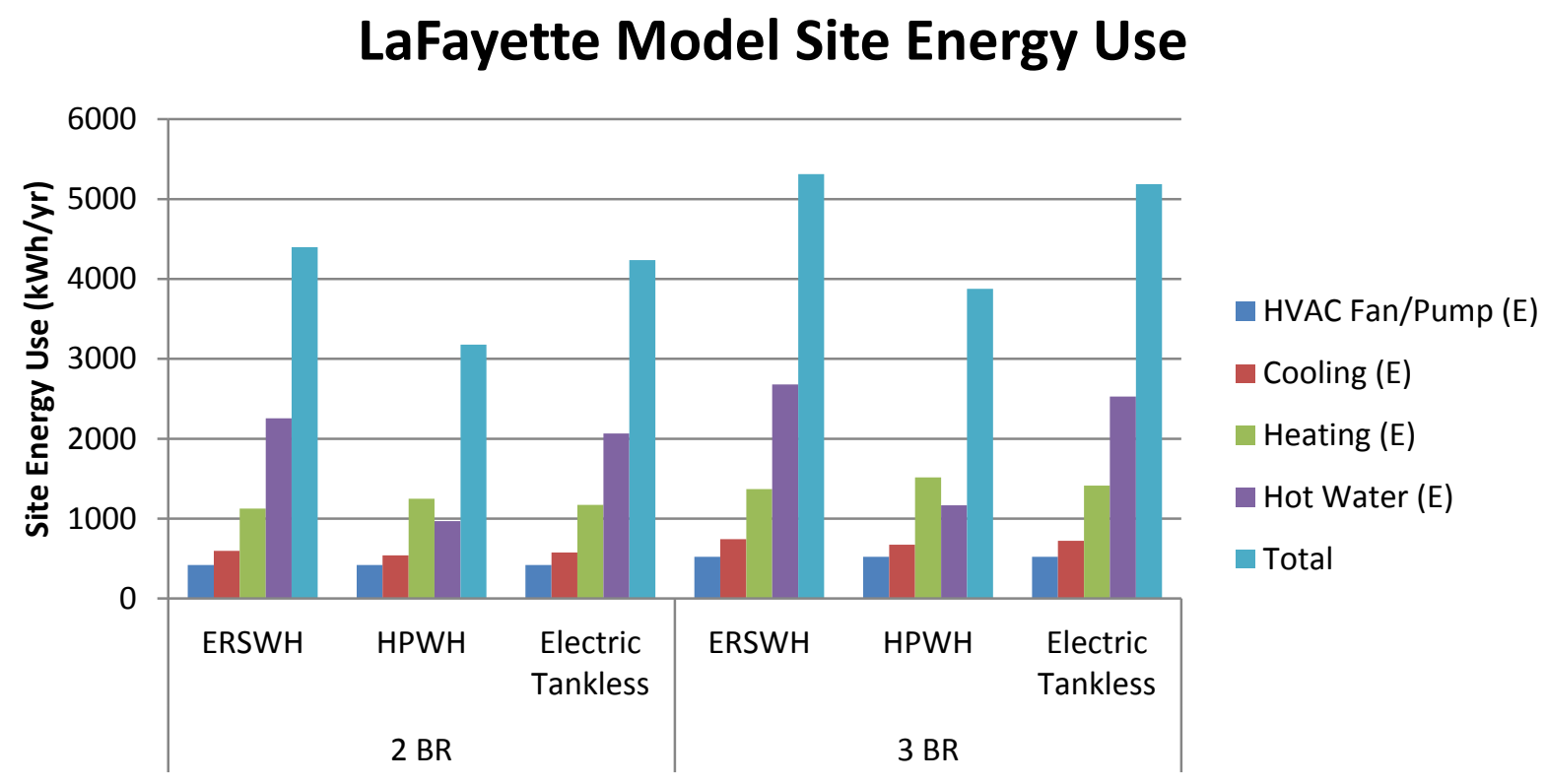

Figure 7. Site energy consumption of the typical two- and three-bedroom duplex units in LaFayette, Georgia

\section{Savannah Model Site Energy Use}

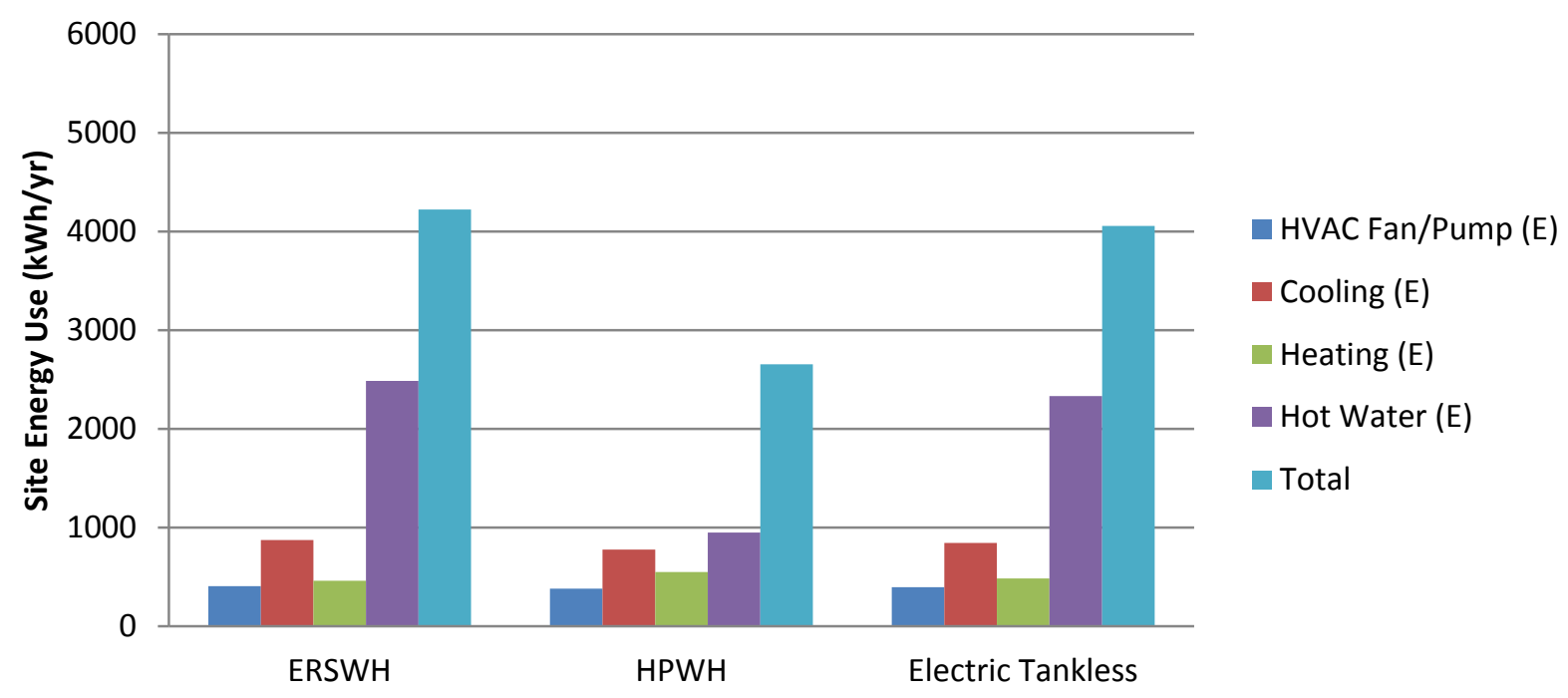

Figure 8. Site energy consumption of NCTH in Savannah, Georgia 
Table 2. Model Site Energy Consumption (kWh/yr) and Change from an ERSWH to HPWH. Negative Values Indicate a Net Gain from ERSWH.

\begin{tabular}{c|c|c|c|c|c|c|c|c|c}
\hline & \multicolumn{2}{|c|}{ Two-Bedroom LaFayette } & \multicolumn{2}{c|}{ Three-Bedroom LaFayette } & \multicolumn{4}{c}{ NCTH Savannah } \\
\cline { 2 - 10 } & ERSWH & HPWH & $\begin{array}{c}\text { HPWH } \\
\text { Savings }\end{array}$ & ERSWH & HPWH & $\begin{array}{l}\text { HPWH } \\
\text { Savings }\end{array}$ & ERSWH & HPWH & $\begin{array}{l}\text { HPWH } \\
\text { Savings }\end{array}$ \\
\hline HVAC Fan/Pump (E) & 419 & 419 & 0 & 522 & 522 & 0 & 404 & 381 & 23 \\
Cooling (E) & 598 & 539 & 59 & 744 & 674 & 70 & 873 & 777 & 97 \\
Heating (E) & 1,125 & 1,249 & -123 & 1,369 & 1,515 & -147 & 460 & 548 & -88 \\
DHW (E) & 2,257 & 970 & 1,287 & 2,679 & 1,166 & 1,512 & 2,485 & 950 & 1,536 \\
Total & 4,399 & 3,177 & 1,222 & 5,314 & 3,877 & 1,436 & 4,223 & 2,655 & 1,568 \\
\hline
\end{tabular}




\subsection{Monitoring Approach}

Long-term monitoring was conducted for 6-9 months after the NCTH dwellings were occupied. Flow and temperature sensors were installed on the HPWH plumbing systems, which were used to calculate the energy transferred to the water. Temperature and RH sensors were installed at the HPWH air intake and exhaust streams. Five sensors were installed in each NCTH attic to monitor temperature and $\mathrm{RH}$ at each of the four wall orientations and the attic center. The home adjacent to the NCTH in Savannah, Georgia, had monitors deployed in the attic as a reference point for an attic with an ERSWH. Both homes in Savannah were also monitored for living zone temperature and RH. Circuit monitors were installed to collect HPWH fan, compressor, and total power consumption in watts. All monitoring equipment recorded data at 1-min intervals. The collected data were used to compute COPs and to analyze temperature and $\mathrm{RH}$ variations, water consumption patterns of HPWHs, and energy balances to investigate the effect on wholebuilding heating, cooling, and moisture loads.

\subsection{Monitoring Equipment}

Monitoring for this project involved the following equipment (Table 3):

Table 3. Monitoring Equipment and Purpose

\begin{tabular}{|c|c|c|c|}
\hline $\begin{array}{c}\text { Parameter of } \\
\text { Interest }\end{array}$ & $\begin{array}{l}\text { Monitor } \\
\text { Type }\end{array}$ & Purpose & Accuracy \\
\hline $\begin{array}{l}\text { Btu DHW } \\
\text { Delivered }\end{array}$ & $\begin{array}{l}\text { Badger in- } \\
\text { line Btu } \\
\text { meter }\end{array}$ & $\begin{array}{l}\text { Measures temperatures of cold water } \\
\text { supply and DHW outlet lines and flow } \\
\text { rate at the water heater. }\end{array}$ & $\begin{array}{l} \pm 0.3^{\circ} \mathrm{C}, \pm 2 \% \\
\text { of flow rates } \\
\text { higher than } \\
1.65 \mathrm{gal} / \mathrm{min}\end{array}$ \\
\hline $\begin{array}{c}\text { Power } \\
\text { Consumption }\end{array}$ & $\begin{array}{l}\text { Trendpoint } \\
\text { Enersure }\end{array}$ & $\begin{array}{l}\text { Power meter capable of reading } \\
\text { multiple circuit transducers to monitor } \\
\text { total electric consumption and } \\
\text { component level power of the HPWH. }\end{array}$ & $\pm 1 \%$ \\
\hline $\begin{array}{l}\text { Duct Air } \\
\text { Temperature } \\
\text { and Humidity }\end{array}$ & $\begin{array}{l}\text { Vaisala in- } \\
\text { duct } \\
\text { temperature } \\
\text { and humidity } \\
\text { probe }\end{array}$ & $\begin{array}{l}\text { Measure the temperature and humidity } \\
\text { of the air stream within the duct just } \\
\text { before air enters and just after the air } \\
\text { leaves the HPWH. }\end{array}$ & $\begin{array}{c} \pm 0.3^{\circ} \mathrm{C} \\
\pm 3 \% \mathrm{RH}\end{array}$ \\
\hline $\begin{array}{l}\text { Attic and } \\
\text { Room } \\
\text { Temperature } \\
\text { and Humidity }\end{array}$ & $\begin{array}{l}\text { OmniSense } \\
\text { wireless } \\
\text { temperature } \\
\text { and RH } \\
\text { sensors }\end{array}$ & $\begin{array}{l}\text { Measure changes in temperature and } \\
\text { humidity to determine the impact of } \\
\text { the HPWH on attic and occupied } \\
\text { space conditions. }\end{array}$ & $\begin{array}{c} \pm 0.4^{\circ} \mathrm{C} \\
\pm 3.5 \% \mathrm{RH}\end{array}$ \\
\hline
\end{tabular}

Figure 9 shows an image of the heat pump with the intake grille/filter removed to show the location of the components, the installed Vaisala Probe, and circuit transducers on the HPWH's main, compressor, and fan power lines. Images of the installed water flow meter and thermocouples (Figure 27) and the heat pump intake side with the grille/filter (Figure 28) are shown in Section 3.8. 


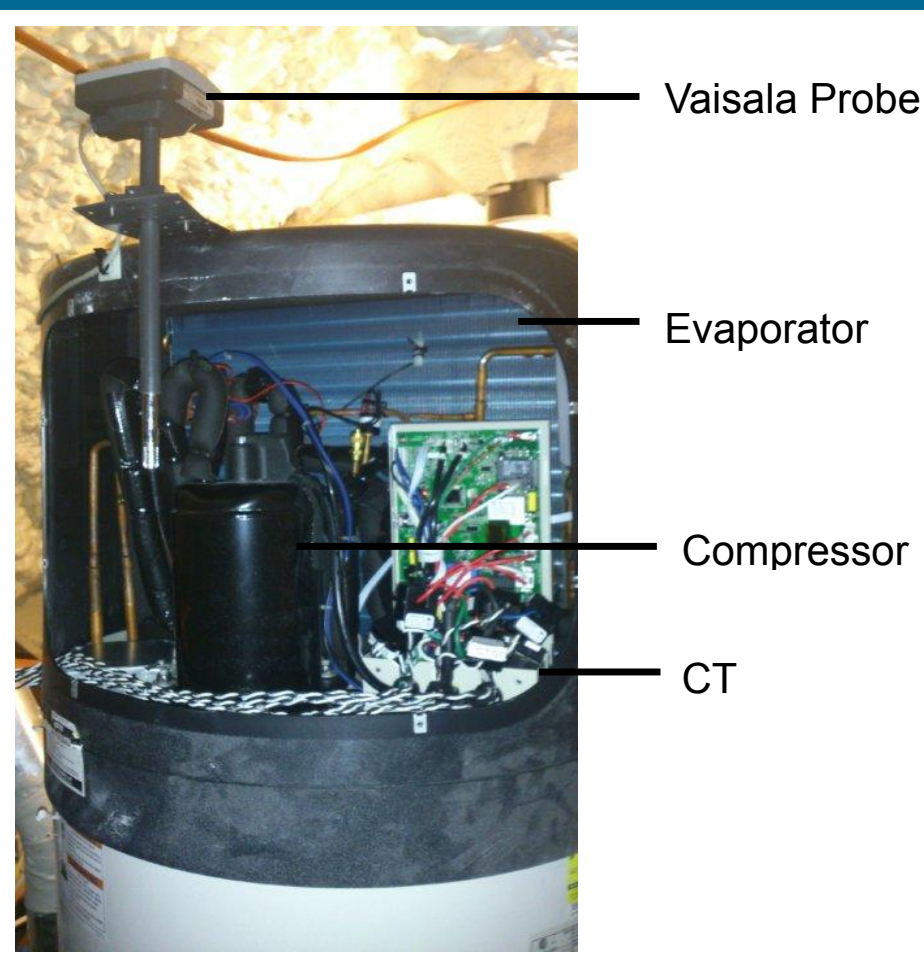

Figure 9. Monitoring equipment installed on the air intake side of the heat pump

\subsection{Monitoring Status}

Table 4 shows a timeline that summarizes all the monitoring equipment and occupancy activity of both sites. All equipment is installed and has transmitted data to Southface's server since April 11, 2014, in LaFayette, Georgia, and July 9, 2014, in Savannah, Georgia.

Table 4. Timeline of Monitoring Equipment and Dwelling Occupancy Activity. Units A, B, C, and D Are in Lafayette and Units $E$ and $F$ Are in Savannah.

\begin{tabular}{c|c|c}
\hline Date & Location & Activity \\
\hline $\mathbf{2 / 2 1 / 2 0 1 4}$ & LaFayette A & Data of occupied units being received. \\
$\mathbf{3 / 1 0 / 2 0 1 4}$ & Savannah E and F & $\begin{array}{r}\text { Data being received (but units were unoccupied). DHW } \\
\text { flow meter entered into state of error. }\end{array}$ \\
$\mathbf{3 / 1 3 / 2 0 1 4}$ & Savannah E and F & Internet connection lost; stopped receiving data. \\
$\mathbf{3 / 2 5 / 2 0 1 4}$ & LaFayette A & $\begin{array}{r}\text { Data connection interrupted. Homeowner turned breaker off } \\
\text { to exterior light controlled by photodiode, which was the } \\
\text { same circuit as monitoring equipment. }\end{array}$ \\
$\mathbf{4 / 1 1 / 2 0 1 4}$ & LaFayette A, B, C, & $\begin{array}{r}\text { Data connection restored. Data from all four units were } \\
\text { being received but B and C were still unoccupied. }\end{array}$ \\
$\mathbf{5 / 1 / 2 0 1 4}$ & LaFayette B & Data of occupied unit being received. \\
$\mathbf{6 / 1 / 2 0 1 4}$ & LaFayette C & Data of occupied unit being received. \\
$\mathbf{7 / 7 / 2 0 1 4}$ & LaFayette D & Unit was unoccupied. \\
$\mathbf{7 / 9 / 2 0 1 4}$ & Savannah E and F & Flow meter was replaced in E. All pertinent data being \\
received from E and D.
\end{tabular}




\section{Performance Results}

\subsection{Analysis}

The COP of the HPWHs, which were operated in efficiency mode only, were evaluated in accordance with NREL's HPWH Field Monitoring Protocol (Sparn et al. 2013). Equation 1 was used to compute the COP:

$$
C O P=\frac{Q_{\text {thermal }}}{W_{\text {input }}}=\frac{\rho_{\text {water }} \cdot V_{\text {draws }} \cdot C_{p, w a t e r} \cdot \Delta T_{\text {draws }}}{W_{\text {input }} \cdot 3600 \frac{s}{h r}}
$$

where:

$\rho_{\text {water }}$ is the density of water

$\mathrm{V}_{\text {draws }}$ is the volume of the water drawn

$\mathrm{C}_{\mathrm{p} \text {,water }}$ is the specific heat of water

$\Delta \mathrm{T}_{\text {draws }}$ is the difference between the outlet $\left(\mathrm{T}_{\text {out }}\right)$ and inlet $\left(\mathrm{T}_{\text {in }}\right)$ water temperature

$\mathrm{W}_{\text {input }}$ is the electrical energy consumed by the HPWH

$\Delta \mathrm{T}_{\text {draws }}$ values were calculated every minute during draw periods, and the value of $\Delta \mathrm{T}_{\text {draws }}$ used in the COP calculations represents the average of $\Delta \mathrm{T}_{\text {draws }}$ during the corresponding time period.

Data were analyzed during time frames when each unit met the following criteria:

- Occupied

- No obvious signs of missing data due to equipment malfunction such as:

- Long periods during which the power consumption data were $0 \mathrm{~W}$ with significant DHW draws. In a few instances the power monitoring equipment froze, stopped delivering data, and rebooted automatically.

- When flow meter data indicated consumption of several hundred gallons over short, unrealistic stretches of time. This was a rare occurrence; the impeller may have stopped in a resonance frequency position.

Periods during which the data did not meet the above criteria were disregarded. Table 5 reports the number of monitored days that were included in the analysis in addition to the number of adults and children who occupied each unit. Units in LaFayette are hereafter referred to as Units A, B, C, and D; the unit in Savannah is referred to as Unit E. Increased number of occupants correlated well with increased DHW consumption; however, the ages of the children were unknown. LaFayette $\mathrm{D}$ was occupied by two sets of tenants during the monitoring period. The first set occupied the unit from April 11, 2014 to July 7, 2014. Then the unit remained unoccupied until September 30, 2014, when the second set of tenants took occupancy. 
Table 5. Number of Monitored Days, Number of Occupants, and Average Daily DHW Use for Each Monitored Site

\begin{tabular}{c|c|c|c}
\hline Site & $\begin{array}{c}\text { Days } \\
\text { Monitored }\end{array}$ & $\begin{array}{c}\text { Adults }+ \\
\text { Children }\end{array}$ & $\begin{array}{c}\text { Average Daily DHW Use } \\
\text { (gal) }\end{array}$ \\
\hline LaFayette A & 290 & $1+2$ & 76.5 \\
\hline LaFayette B & 236 & $1+1$ & 27.1 \\
\hline LaFayette C & 178 & $1+1$ & 55.1 \\
LaFayette D & 100 & $1+1$ then $1+2$ & $41.6^{*}$ \\
\hline Savannah E & 174 & $1+2$ & 61.2 \\
\hline
\end{tabular}

*Combined average from both sets of tenants

\subsection{Uncertainty Analysis}

An uncertainty analysis was performed by propagating the error of each sensor measurement that is used to calculate COP. Sensor accuracies are listed in Table 3. First, the uncertainty of $\Delta \mathrm{T}_{\text {draws }}$ was calculated using Eq. 2.

$$
\delta \Delta T=\sqrt{\left(\delta T_{\text {out }}\right)^{2}+\left(\delta T_{\text {in }}\right)^{2}}
$$

The uncertainty of $\Delta \mathrm{T}_{\text {draws }}$ was calculated to be $\pm \sqrt{0.18}$. Total COP uncertainty can be approximated using Eq. 3.

$$
\frac{\delta C O P}{C O P}= \pm \sqrt{\left(\frac{\delta V_{\text {draws }}}{V_{\text {draws }}}\right)^{2}+\left(\frac{\delta W_{\text {input }}}{W_{\text {input }}}\right)^{2}+\left(\frac{\delta \Delta T_{\text {draws }}}{\Delta T_{\text {draws }}}\right)^{2}}
$$

Total COP uncertainty was determined to be $\pm 3.1 \%$. An example uncertainty for daily parameters is shown in Table 6.

Table 6. Uncertainty for Example Daily Values

\begin{tabular}{c|c|c}
\hline Metric & $\begin{array}{c}\text { Daily } \\
\text { Value }\end{array}$ & $\begin{array}{c}\text { Daily } \\
\text { Uncertainty }\end{array}$ \\
\hline COP & 2.4 & \pm 0.07 \\
Daily $\mathbf{V}_{\text {draws }}($ gal) & 47.8 & \pm 1.0 \\
Daily $\Delta \mathbf{T}_{\text {draws }}\left({ }^{\circ} \mathbf{C}\right)$ & 22.7 & \pm 0.3 \\
Daily $\mathbf{W}_{\text {input }}(\mathbf{k W h})$ & 2.8 & \pm 0.03 \\
\hline
\end{tabular}

\subsection{Comparison of Set Point Temperatures}

The tenants of LaFayette had no access to the HPWHs, which were located in locked mechanical closets to protect the equipment; this is a common practice in rental housing. The homeowner of the NCTH in Savannah (E) had access to the HPWH in the attic and could adjust the set point temperature and operating mode. Data indicated the HPWH was unintentionally set to vacation mode on August 21, 2014, because several DHW draws occurred between August 21 and August 23 without the heat pump operating and the HPWH outlet water temperature decreased significantly (Figure 10). The homeowner was apparently not satisfied with the $82^{\circ} \mathrm{F}$ water at the spigot, so they turned the HPWH to efficiency mode and increased the set point temperature on 
August 23, 2014. The HPWH power consumption and output water temperature increased, but the patterns remained the same after the event, whereas a change to hybrid or electric mode would have caused a different power consumption pattern. The HPWH compressor's power consumption was higher because more work was required to move heat into a tank at a higher temperature.

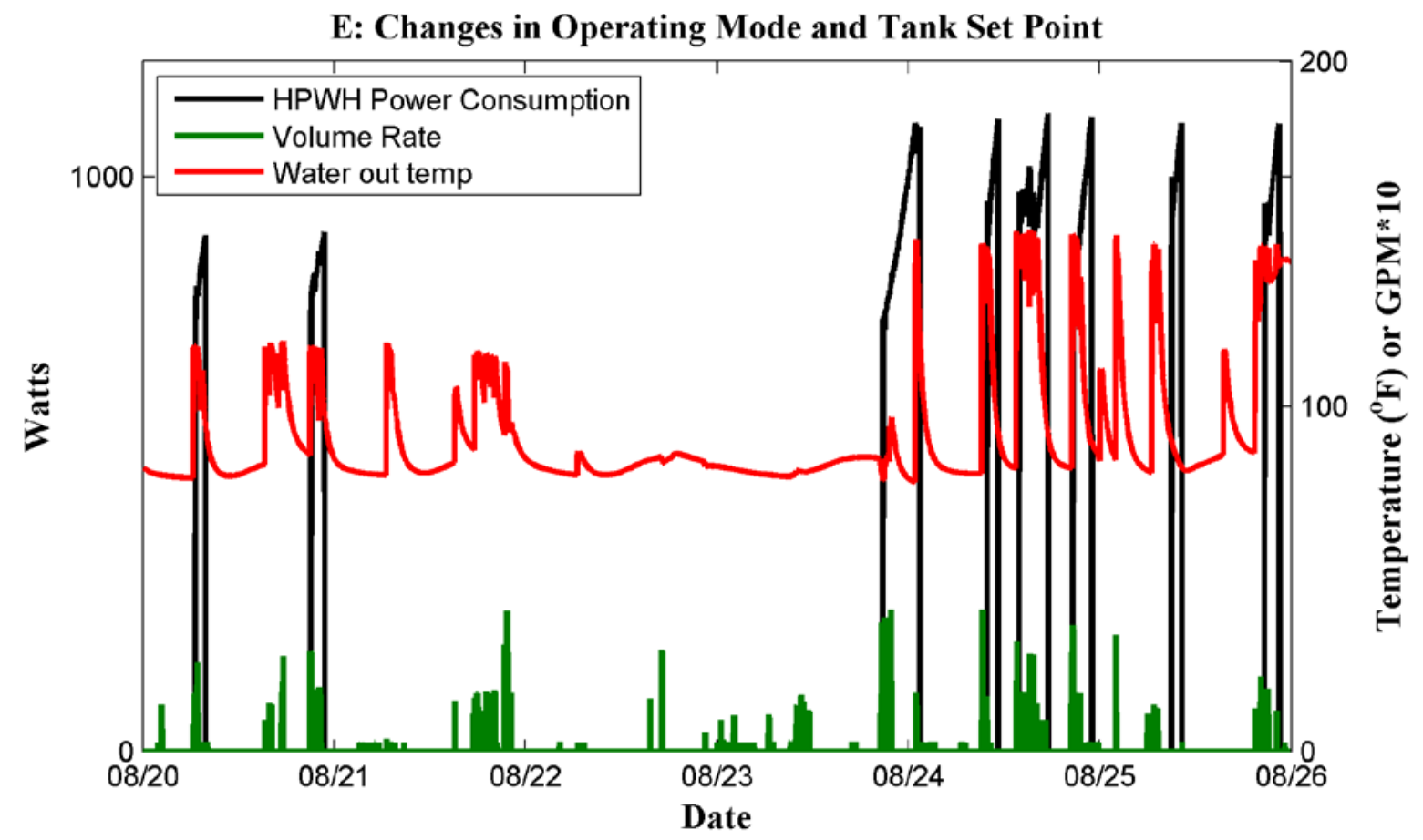

Figure 10. Changes in the HPWH operating mode and tank set point temperature can be seen in the raw data

Unit E was segregated into two periods (E1 and E2) for analysis based on the differing tank set points (Table 7) and other critical daily averages that affected HPWH performance. E1 reflects the period from July 9 to August 20, and E2 reflects the period from August 24 through October 15. Figure 11 shows a graph of the processed daily averages of HPWH inlet and outlet temperatures used for the daily COP calculations. The average water outlet temperature during E1 was $113.5^{\circ} \mathrm{F}$ when the tank set point temperature was $120^{\circ} \mathrm{F}$. The lower measured temperature was due to thermal losses from the measuring equipment and short water draws, which are addressed later in the document. The average daily water outlet temperature during E2 was $133.1^{\circ} \mathrm{F}(17.3 \%$ increase $)$, it peaked slightly higher than $140^{\circ} \mathrm{F}$, and the set point temperature was verified to be $150^{\circ} \mathrm{F}$ (the HPWH maximum). The daily average change in water temperature across the tank increased by $19.4^{\circ} \mathrm{F}$, a $54.4 \%$ increase; the inlet water temperature increased by only $0.4 \%$. The higher set point is associated with a lower average daily COP value of 2.0 compared to the $120^{\circ} \mathrm{F}$ set point average daily COP of 3.1 . 
Table 7. Unit E Time Frames of Differing Tank Set Points

\begin{tabular}{|c|c|c|c|}
\hline & $\begin{array}{c}\text { Savannah E1 } \\
\text { Daily Averages: } \\
\mathbf{1 2 0}^{\circ} \mathbf{F} \text { Set Point }\end{array}$ & $\begin{array}{c}\text { Savannah E2 } \\
\text { Daily Averages: } \\
\mathbf{1 5 0}^{\circ} \mathbf{F} \text { Set Point }\end{array}$ & $\begin{array}{c}\text { Percent } \\
\text { Change }\end{array}$ \\
\hline Date Range of Analysis & $7 / 9 / 14$ to $8 / 20 / 14$ & $8 / 24 / 14$ to $1 / 7 / 15$ & N/A \\
\hline \# of Days & 43 & 53 & $23.3 \%$ \\
\hline $\mathbf{C O P}\left({ }^{\circ} \mathbf{F}\right)$ & 3.1 & 2.0 & $-29.0 \%$ \\
\hline HPWH Energy (kWh) & 35.7 & 55.1 & $54.3 \%$ \\
\hline DHW Use (gal) & 2.2 & 3.5 & $58.5 \%$ \\
\hline HPWH Runtime (min) & 76.6 & 54.8 & $-28.5 \%$ \\
\hline DHW Draw Time (min) & 158.5 & 214.4 & $35.2 \%$ \\
\hline Outlet Water Temperature $\left(^{\circ} \mathbf{F}\right)$ & 51.3 & 49.2 & $-4.0 \%$ \\
\hline Input Air Temperature $\left(^{\circ} \mathbf{F}\right)$ & 77.7 & 78.1 & $0.4 \%$ \\
\hline Input Air RH & 113.5 & 133.1 & $17.3 \%$ \\
\hline
\end{tabular}

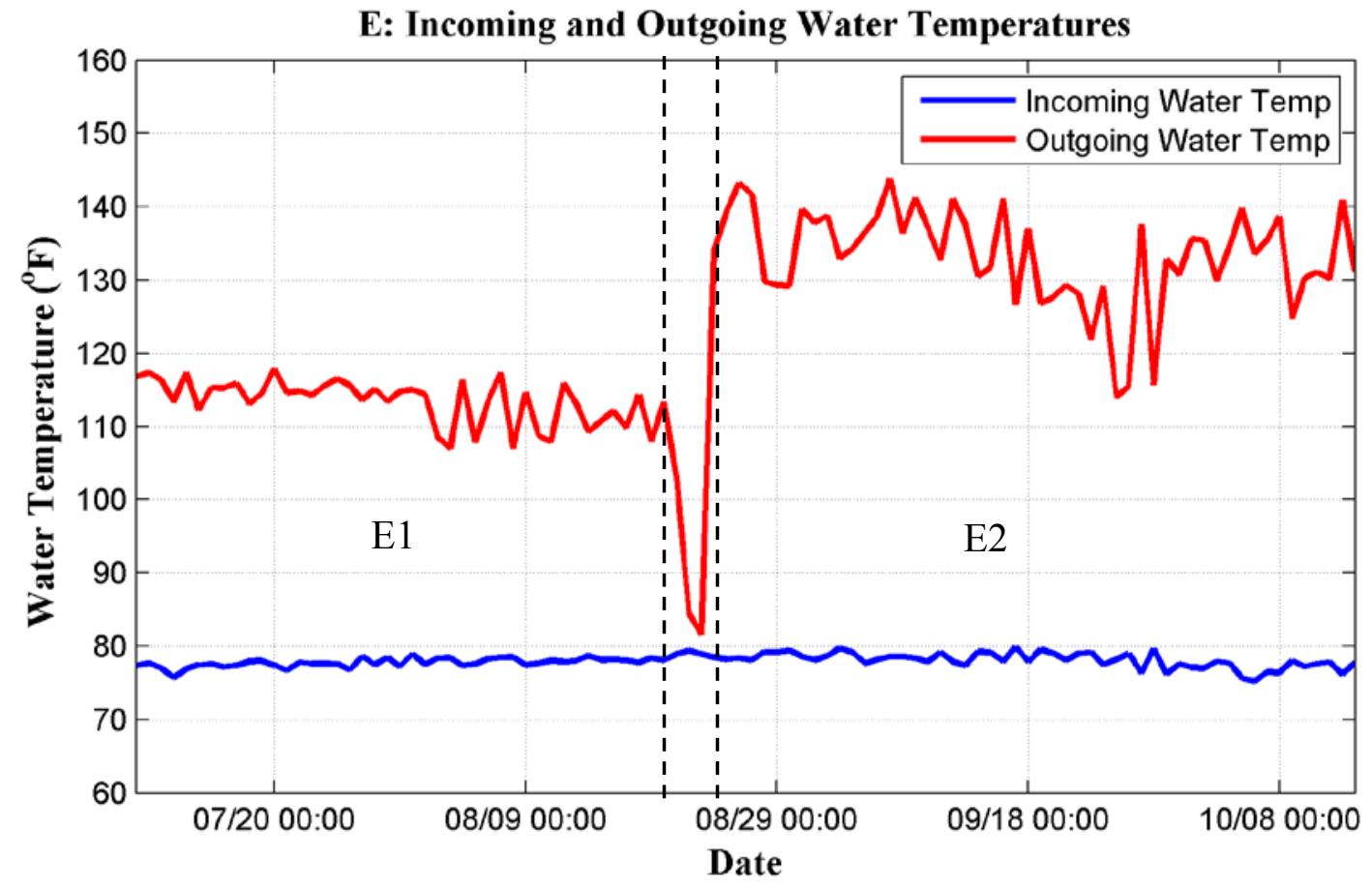

Figure 11. Processed data of daily HPWH incoming and outgoing water temperatures depicting a change in tank set point temperature. E1 includes period to the left of the first dashed line. E2 includes period to the right of the second dashed line.

The average daily volume of hot water consumed decreased by 21.8 gal/day; the daily average DHW draw time decreased by only $2.1 \mathrm{~min}$ after the tank set point was set to $150^{\circ} \mathrm{F}$. Assuming the average temperature at the tap was the same during both periods, an energy balance of mixing hot and cold water streams would require less DHW at the higher temperature. 
Figure 12 displays the trend between daily COP values and daily water consumption for both set points. The COP increases as the consumption increases, and the COP values are generally higher for the lower tank set point temperature. Lower COP values at the higher set point for similar consumptions can be attributed to higher tank losses and a high refrigerant condensing temperature at higher tank set points.

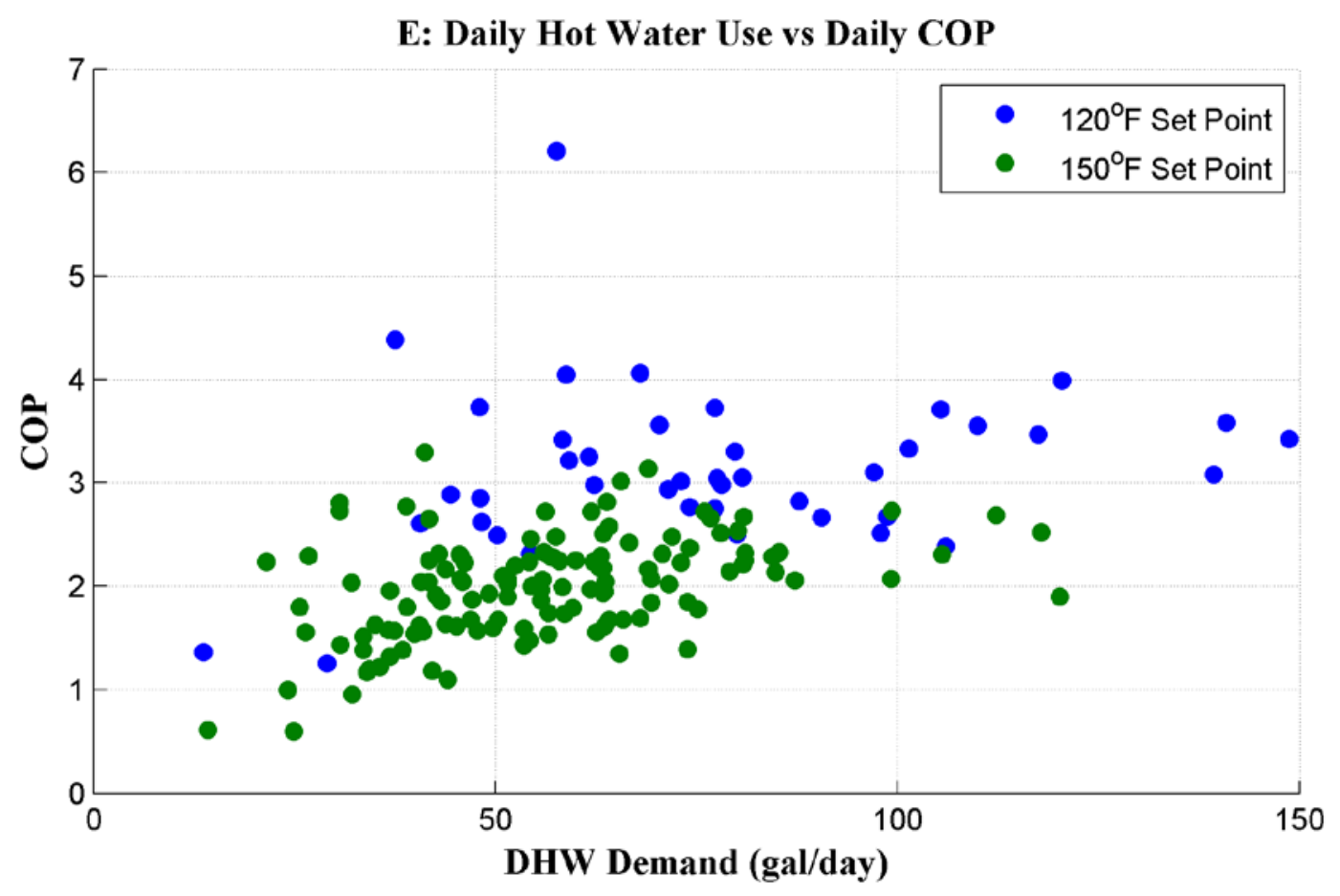

Figure 12. Daily DHW use versus daily COP values for both set points at Savannah E

\subsection{Combined Site Results}

Major variability in daily COP values was observed across the monitoring period (Figure 13 and Figure 14). On most occasions, significantly higher daily COP values were observed at times and lower COPs at others. This random distribution can be largely attributed to the variability in daily DHW use seen in Figure 12. Another reason is the timing of the HPWH turning on. According to A.O. Smith documentation, the HPWH is set to turn on when the tank temperature reaches $9^{\circ} \mathrm{F}$ below set point. On many occasions the heat pump would operate at the beginning or end of a day; thus, the energy consumption was attributed to a different chronological day than the hot water draw actually occurred. This was largely dependent on the behavioral consumption of the hot water. 


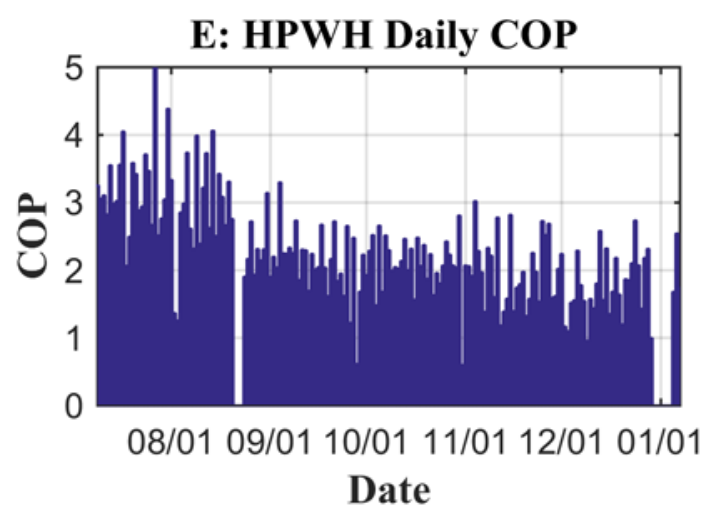

Figure 13. Bar plot of daily COP values for Savannah showing large deviations across the monitored period

A: HPWH Daily COP

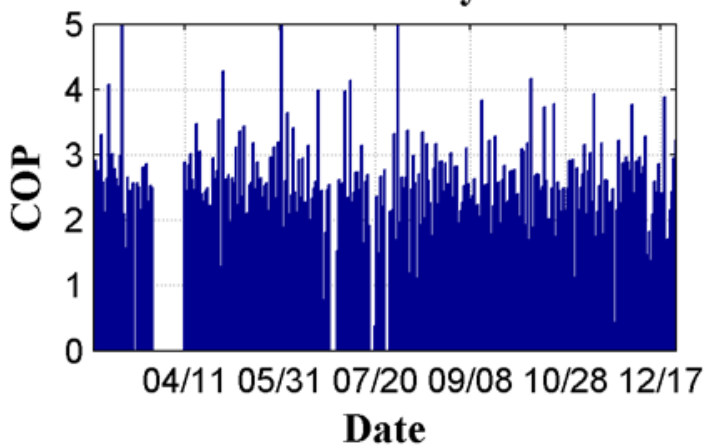

C: HPWH Daily COP

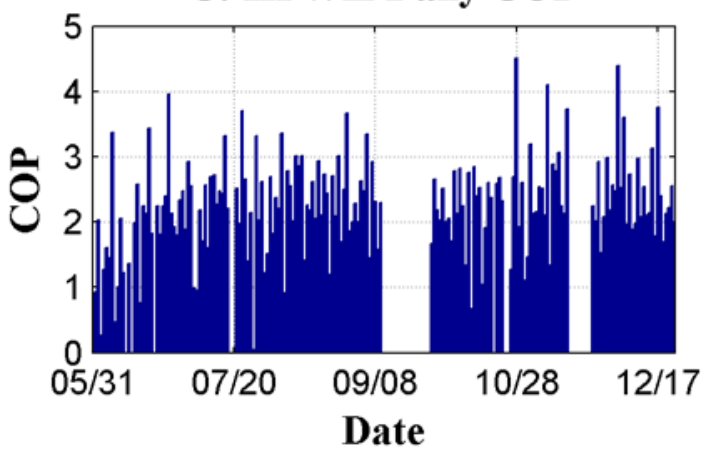

B: HPWH Daily COP

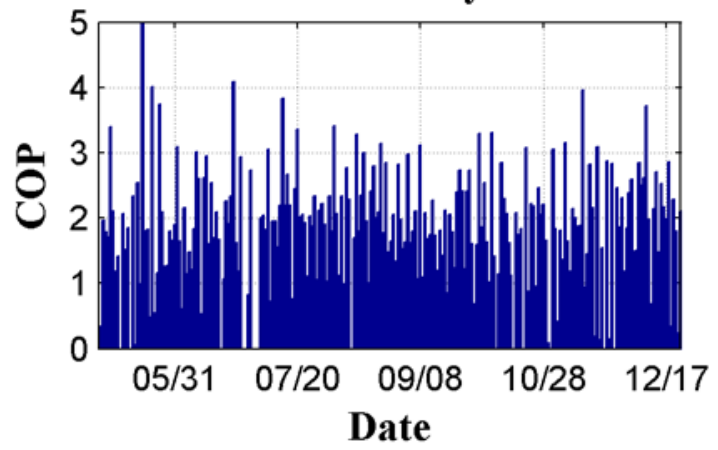

D: HPWH Daily COP

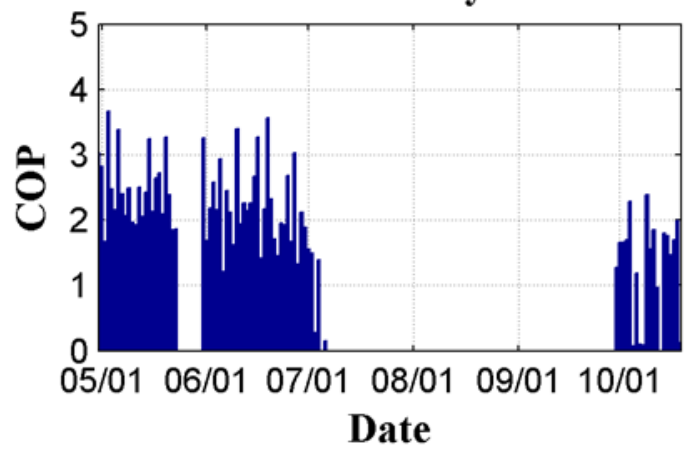

Figure 14. Bar plots of daily COP values of all four units in LaFayette. The bare areas indicate periods that did not meet all criteria to be considered valid data.

When the daily COP calculations were averaged, equal weight was given to the daily COP values. The average daily COP values for a $120^{\circ} \mathrm{F}$ tank set point at the LaFayette site were 1.9 and 2.5 and 3.1 at the Savannah site. Thus, the COP across the entire monitored period was calculated and resulted in a slightly different COP values at each. These results and the daily average values of variables used in the COP calculation are listed in Table 8. 
Table 8. Summary of All Monitored HPWH Daily Average Variables Used To Compute Daily Average COP

\begin{tabular}{|c|c|c|c|c|c|c|c|}
\hline$\stackrel{\mathscr{H}}{\circ}$ & 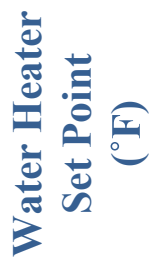 & 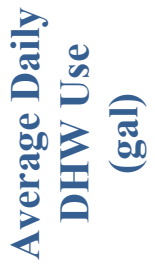 & 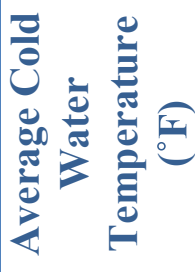 & 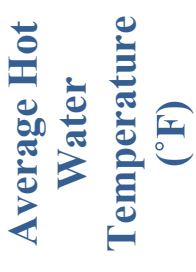 & 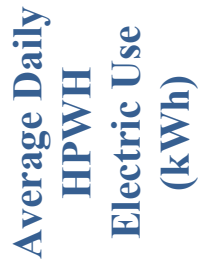 & 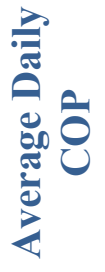 & 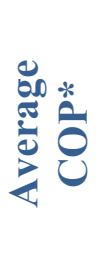 \\
\hline $\mathbf{A}$ & 120 & 76.5 & 68.3 & 111.0 & 3.1 & 2.5 & 2.6 \\
\hline B & 120 & 27.1 & 71.5 & 110.2 & 1.4 & 1.9 & 2.0 \\
\hline C & 120 & 55.1 & 71.1 & 111.5 & 2.4 & 2.2 & 2.4 \\
\hline D & 120 & 41.6 & 70.7 & 109.2 & 1.9 & 2.0 & 2.2 \\
\hline E1 & 120 & 76.6 & 77.7 & 113.5 & 2.2 & 3.1 & 3.0 \\
\hline E2 & 150 & 55.5 & 75.2 & 128.8 & 3.7 & 2.0 & 1.9 \\
\hline
\end{tabular}

*Average COP was calculated across the entire time period.

Figure 15 displays the trend between daily DHW consumption and average daily COP. The COP increased sharply before reaching the knee of the curve between 20-40 gal/day before leveling. This trend was reported by Shapiro and Puttagunta (2013). They reported an average COP value of 2.1 for the unducted A.O. Smith Voltex models.

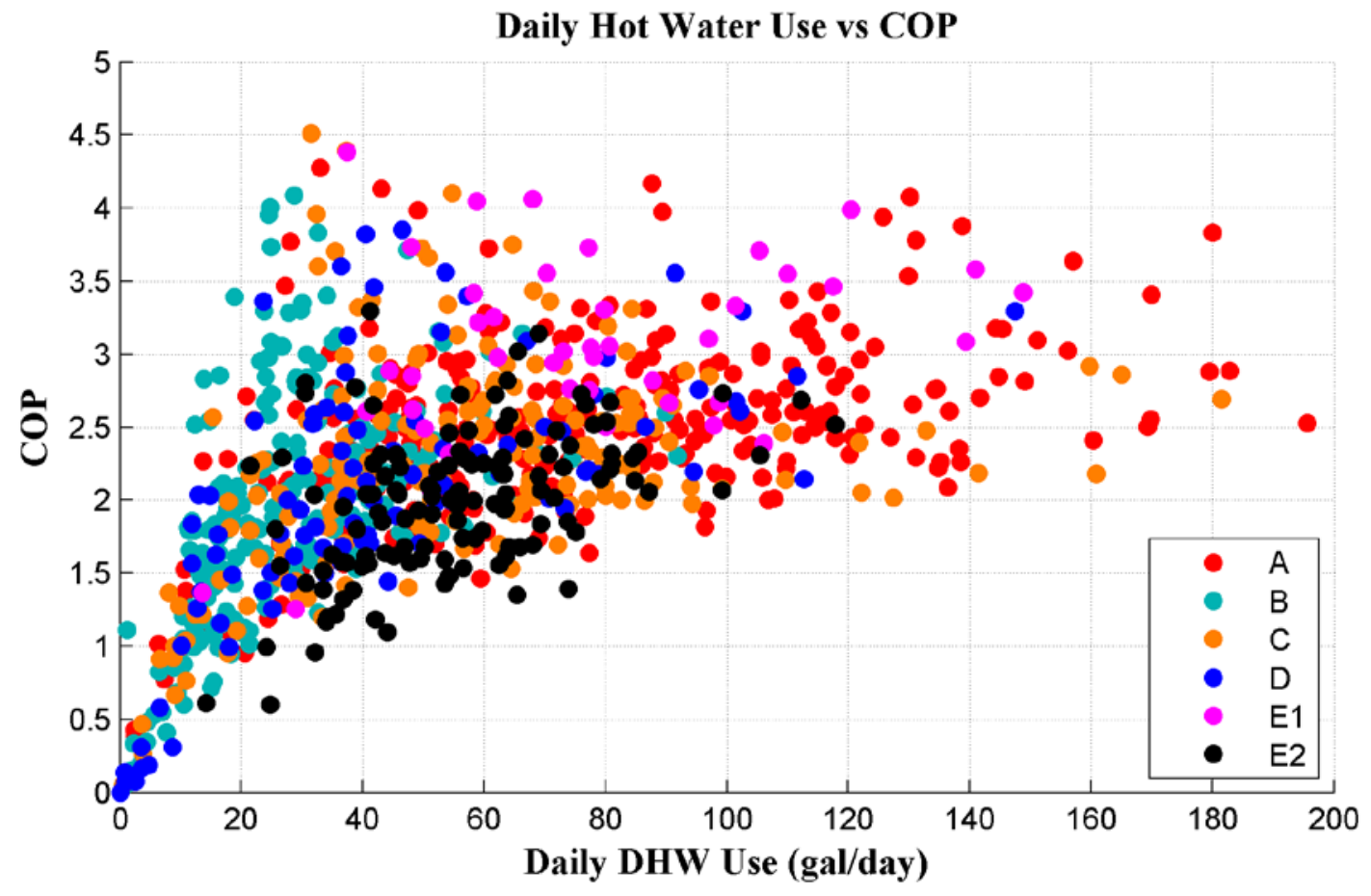

Figure 15. Scatter plot of daily DHW use versus COP for all five units 
Figure 16 displays the dependence of daily HPWH energy consumption on daily DHW consumption and daily average $\Delta \mathrm{T}$ of tank inlet and outlet water. The energy consumption increases linearly as the DHW consumption increases. The energy consumption increases at a faster rate as the $\Delta \mathrm{T}$ of tank inlet and outlet water increases. Royal blue dots (recorded from house D) in the lower left corner represent days when few water draws occurred and the heat pump never operated, when no draw occurred but the heat pump operated due to tank losses, or a combination of both.

\section{HPWH Electric Use for Varied dTs and Hot Water Demand}

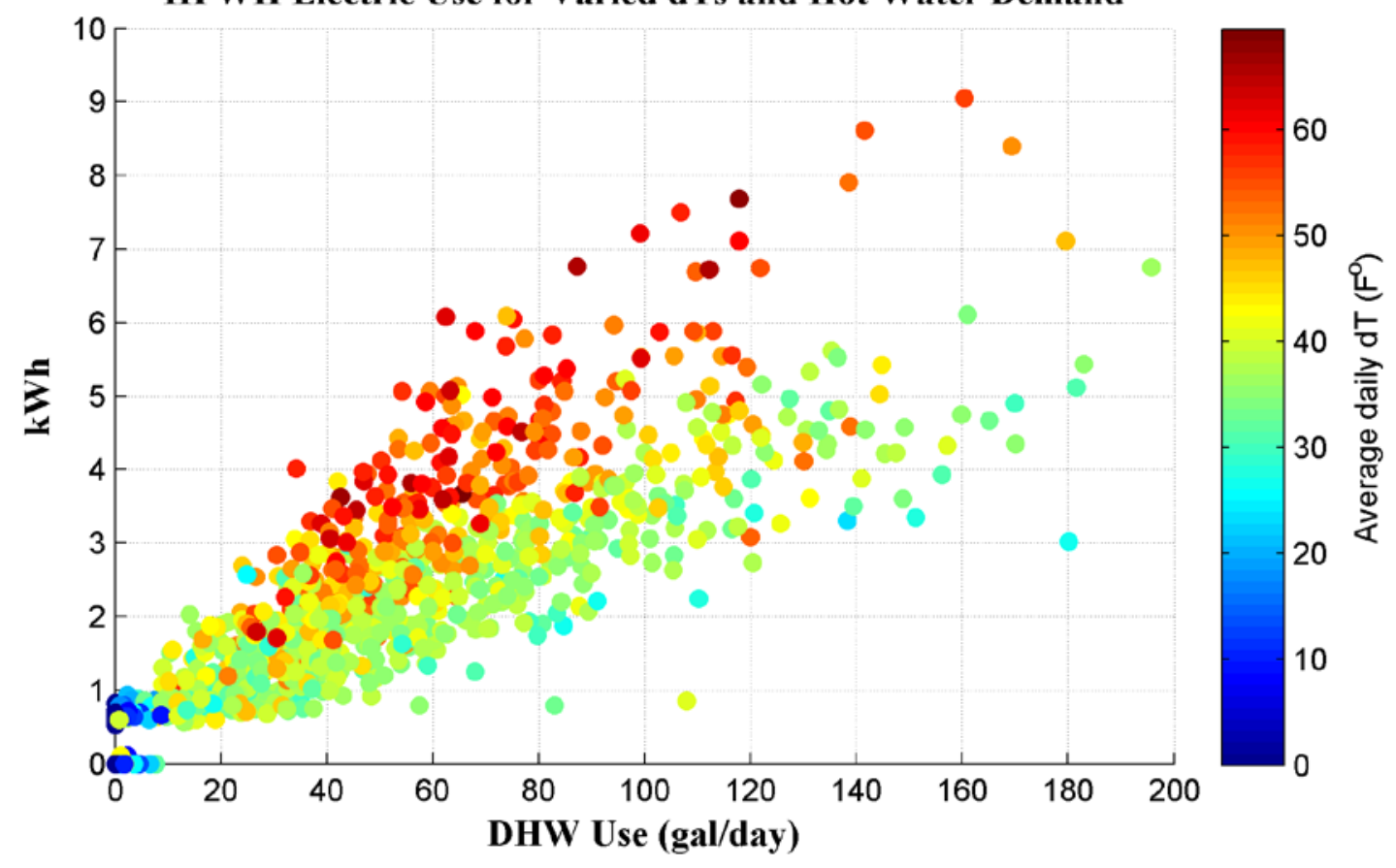

Figure 16. Daily HPWH energy consumption as a function of daily DHW use and daily average $\Delta T$ across the tank

Figure 17 plots the intake wet bulb temperatures directly against the daily COPs. Unit E1 (pink), in Savannah, Georgia, with a $120^{\circ} \mathrm{F}$ set point, appears to have predominantly higher intake air wet bulb temperatures and daily COP values than the other units. E1 did have the highest daily average COP. Otherwise, no individual unit shows an apparent trend linking increased intake air wet bulb temperature to increased COP values. 


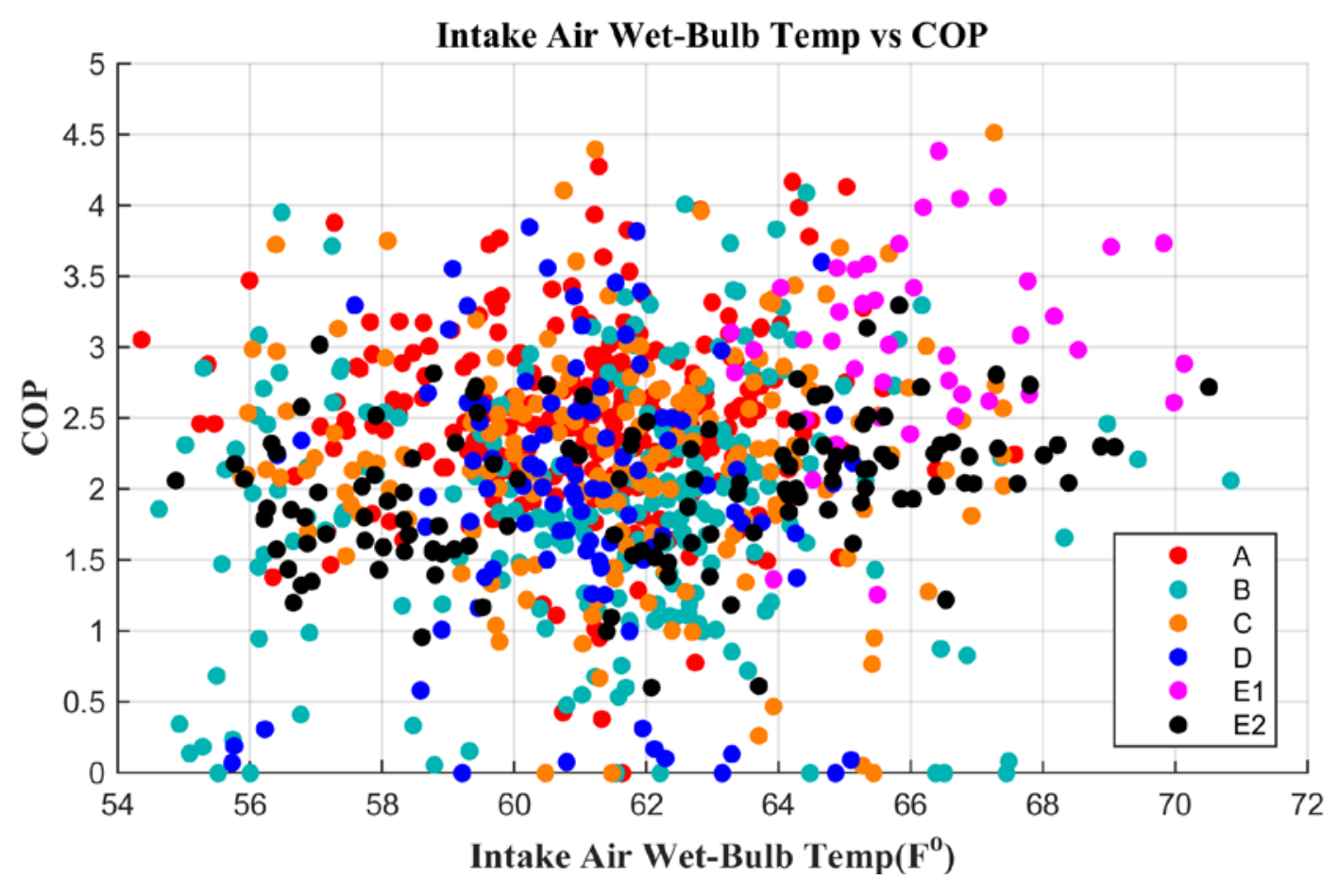

Figure 17. Intake air wet bulb temperature and daily average COP

\subsection{Effect of Duct Configurations in LaFayette}

All HPWHs at the beginning of the monitoring period were configured with an unducted intake and ducted exhaust directly to the encapsulated attic. The intake pulled air from the attic through a transfer grille in the ceiling. Configurations at Units A and B were adjusted on September 17, 2014 , to evaluate the performance impact of various duct configurations. A duct kit was installed on the intake sides of both units and connected to the hole where the transfer grille was removed via 8-in. insulated (R-6) flex duct (Figure 18 and Figure 19). A.O. Smith said that the relief vents on the bottoms of the duct kits could be sealed off without harming the HPWH and provided flexible adhesive strips to seal the vents (Figure 20). The flexible strips proved difficult to install but successfully blocked all air leakage, so duct mask was applied. Both the supply and exhaust were ducted in this configuration for Units A and B.

On September 26, 2014, the exhaust duct on unit B was removed so the HPWH exhausted air directly into the mechanical closet. The duct that connected the closet to the attic remained open to determine the impact of increased pressure from excessive ducting. 

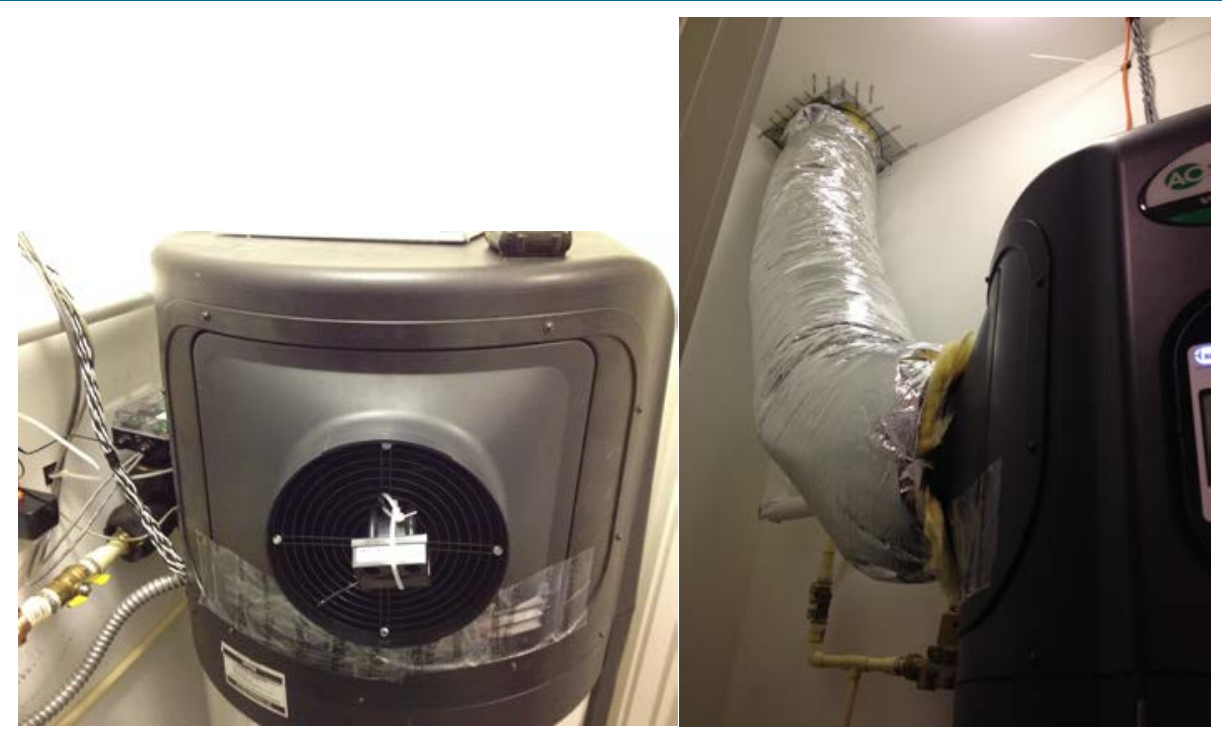

Figure 18. Intake ducting installation at Site A duct kit installed on the intake side with temperature/RH sensor attached to the grille (left); insulated 8-in. flex duct connecting the duct to the attic (right)

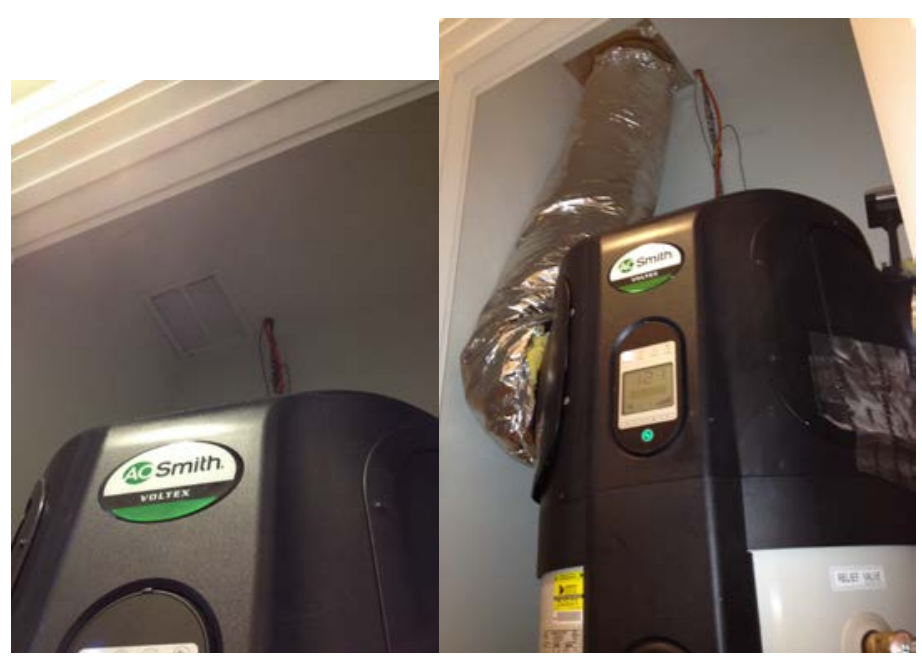

Figure 19. Intake duct configuration at Site B. Transfer grille in the ceiling before being removed (left); ducted intake grille and sealed exhaust relief vent (right)

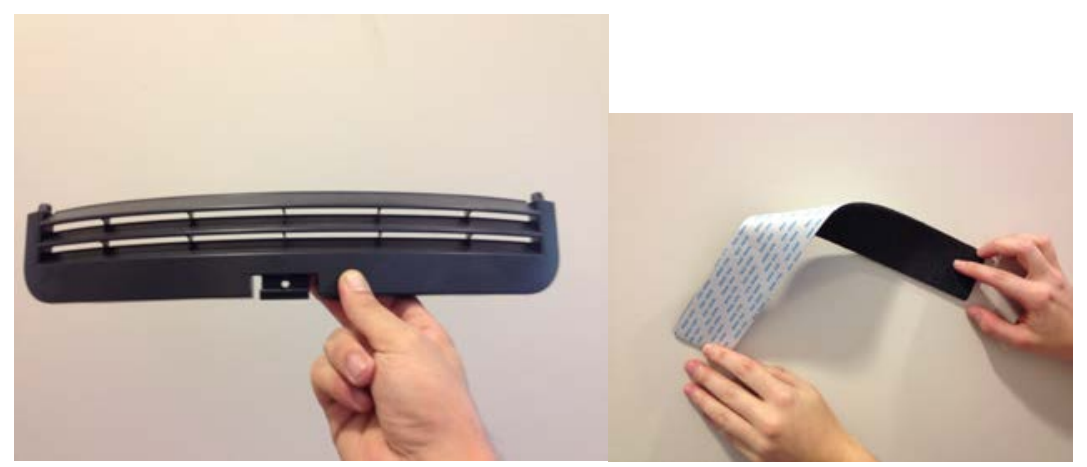

Figure 20. Relief vent grille supplied with the duct kits (left); flexible adhesive strip supplied by A.O. Smith to seal the relief vent (right) 
To compare HPWH performance under various ducting configurations, variables were analyzed for equivalent durations directly before and after the duct configuration changes. Table 9 documents the date ranges of the HPWH duct configurations and the corresponding average daily COP values. The COP values remained the same for Units A and B with intake ducting and for Unit C, whose duct configuration remained unchanged. A completely unducted HPWH was not tested, because it went against the collaborator and manufacturer's recommendation due to the low volumetric air capacity of the mechanical closet.

Table 9. Date Ranges of Each Site and the Duct Configuration Applied

\begin{tabular}{|c|c|c|c|c|c|c|c|}
\hline Site & Location & $\begin{array}{c}\text { Time } 1 \\
\text { 8/26-9/16 }\end{array}$ & $\begin{array}{c}\text { Time 1 } \\
\text { Average } \\
\text { Daily } \\
\text { DHW Use } \\
\text { (gal) }\end{array}$ & $\begin{array}{c}\text { Time } 1 \\
\text { Average } \\
\text { Daily } \\
\text { COP }\end{array}$ & $\begin{array}{c}\text { Time } 2 \\
\text { 9/18-10/19 }\end{array}$ & $\begin{array}{c}\text { Time } 2 \\
\text { Average } \\
\text { Daily DHW } \\
\text { Use (gal) }\end{array}$ & $\begin{array}{c}\text { Time } 2 \\
\text { Average } \\
\text { Daily } \\
\text { COP }\end{array}$ \\
\hline \multirow[t]{2}{*}{ A } & Intake & & \multirow{2}{*}{82.7} & \multirow{2}{*}{2.5} & X & \multirow{2}{*}{86.9} & \multirow{2}{*}{2.5} \\
\hline & Exhaust & $\mathrm{X}^{*}$ & & & X & & \\
\hline \multirow[t]{2}{*}{ B } & Intake & & \multirow{2}{*}{27.4} & \multirow{2}{*}{1.8} & X & \multirow{2}{*}{29.8} & \multirow{2}{*}{1.8} \\
\hline & Exhaust & $X$ & & & & & \\
\hline \multirow[t]{2}{*}{0} & Intake & & \multirow{2}{*}{64.7} & \multirow{2}{*}{2.3} & & \multirow{2}{*}{52.5} & \multirow{2}{*}{2.3} \\
\hline & Exhaust & $X$ & & & X & & \\
\hline
\end{tabular}

* $\mathrm{X}$ indicates the location was ducted if the intake or exhaust was ducted.

Figure 21 shows box plots of the intake air temperatures of Units A and B over the preceding period and when the heat pump air intakes were ducted directly to the encapsulated attic. The mean intake air temperature for Unit A increased from $68.9^{\circ} \mathrm{F}$ to $70^{\circ} \mathrm{F}$ when the intake was ducted. The mean intake air temperature for Unit B stayed at $69.7^{\circ} \mathrm{F}$ during both duct configurations, but the daily deviations were much greater. The average air intake of Unit $\mathrm{C}$, which remained unducted during both periods, decreased from $72.8^{\circ} \mathrm{F}$ to $71.4^{\circ} \mathrm{F}$. Aside from general increases and decreases, Unit $\mathrm{C}$ cannot be compared further to Units $\mathrm{A}$ and $\mathrm{B}$ because its intake temperature was always greater, and Units A and B were in the same duplex and shared an uninsulated interior attic wall. Unit C's intake air temperature was warmer over the entire monitoring period even when the other units were ducted. The average daily intake temperature likely had an insignificant impact on the COP because the temperature change was minimal. Ducting the intake would have increased air temperature across the evaporator coil because the recirculating exhaust was eliminated, but the average attic air temperatures varied up to $6^{\circ} \mathrm{F} /$ day and the intake temperature depended on the time of day the heat pump operated. The increased static pressure across the fan - if it was measurable - was caused by the intake duct and did not affect the HPWH's efficiency. 
A: Intake Air Temp

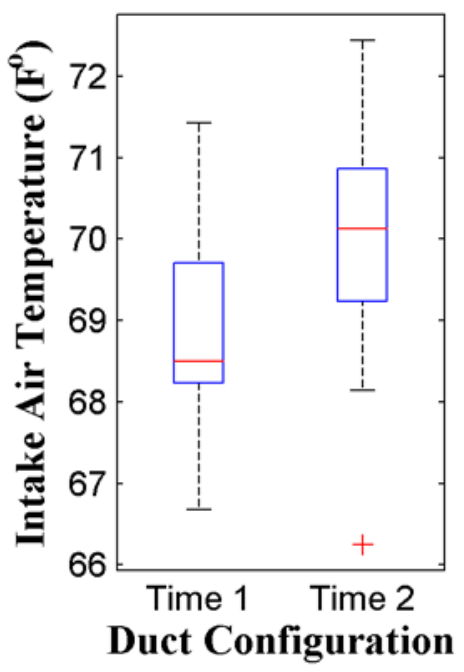

B: Intake Air Temp

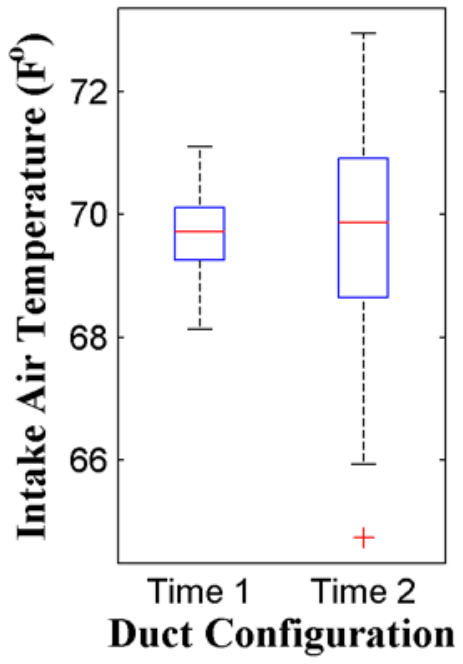

C: Intake Air Temp

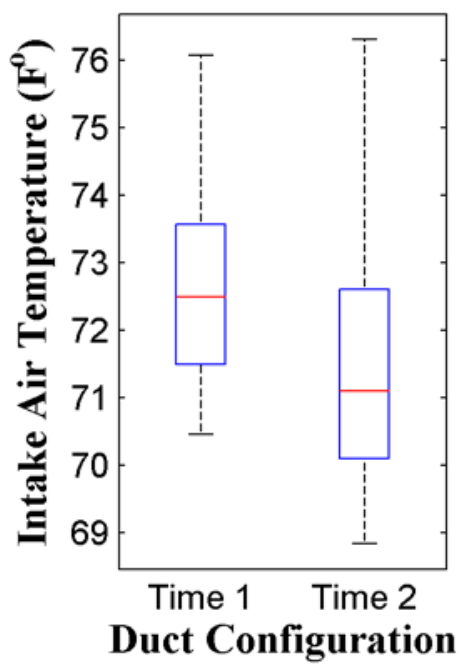

Figure 21. Intake air temperature of Units $A, B$, and $C$ over the periods $T 1=8 / 26 / 14-9 / 16 / 14$ and $T 2$ $=9 / 18 / 14-10 / 19 / 14$. Units $A$ and $B$ had ducted intakes during T2 and Unit C's intake remained unducted for the entire period (+ indicate outliers).

\subsection{Impact on Encapsulated Attic Air Temperature and Humidity}

The impact of the HPWH on the temperature and humidity of the encapsulated attic and the living space was evaluated. Dehumidification in Unit E's attic is clearly observed when the HPWH operated during the summer (Figure 22); however, the airstreams returned to their original states quickly after the HPWH stopped operating. This indicates moisture removal was rather insignificant relative to total attic moisture content. Figure 22 also depicts the temperatures and absolute humidities of the air that entered and exited the HPWH. The exhaust air sensor was installed inside the duct, and its absolute humidity spiked after HPWH operation. During heat pump operation, latent heat was removed from the airstream via condensation that drips from the heat exchanger coils to the drain pan. Internal factory-installed drain lines did not meet flush to the pan to allow it to drain completely. Further, condensation remained on the heat exchanger coils when the heat pump stopped operating. This confined area also houses the compressor, which reached temperatures near $200^{\circ} \mathrm{F}$ (Figure 9). At the conclusion of a heat pump cycle, the condensed water in the pan and on the coil re-evaporated from the heat of the compressor, became trapped in the now-cooled duct, and caused the sensor in the exhaust duct to measure high absolute humidity. Condensation in the cool duct was detected and mold growth within the duct is possible, although none was observed. 

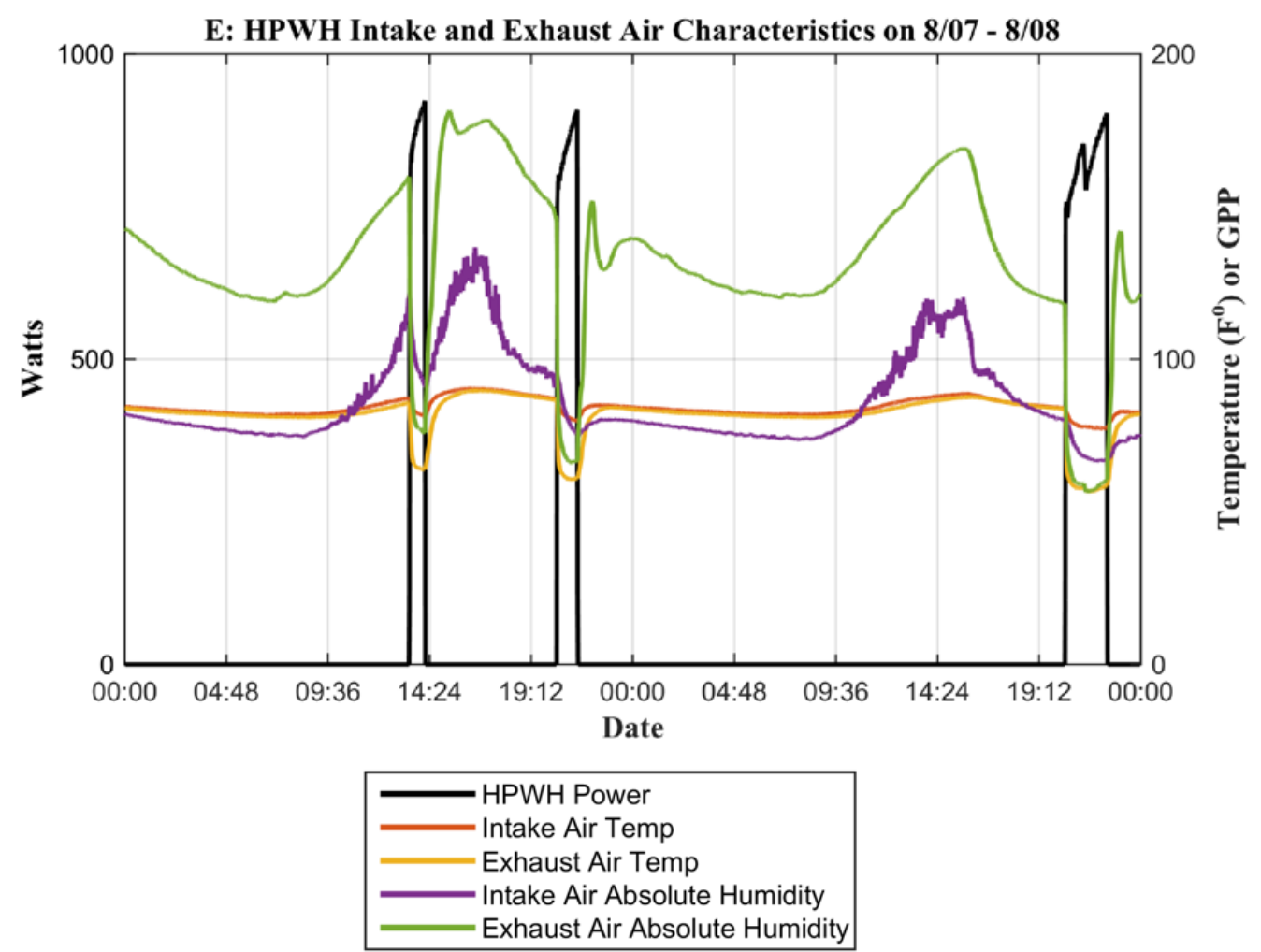

Figure 22. Savannah E HPWH intake and exhaust temperatures and humidities

Figure 23 compares the absolute humidities at the high center location of the attic and of the living space of Unit E (Challenge; the home was seeking U.S. Department of Energy Challenge Home certification) and of the neighboring home (Unit F). The neighboring home is of similar construction (same size, HVAC equipment, and sealed attic) except it has an ERSWH in the attic. The peak absolute humidity level in the attic was reduced only when the HPWH operated before peak times; it generally needed to run during the morning when the humidity levels were rising. When the HPWH operated at other times during the day, the absolute humidity levels almost immediately returned to the same levels as in the neighboring home. The HPWH did not provide significant dehumidification; the humidity decreased only slightly when the HPWH was running. The humidity levels in the living zones were entirely dependent upon the latent heat removal by the HVAC systems.

The fluctuations of the absolute humidity levels in the attics are believed to be highly influenced by the "sponge" effect of open-cell foamed rooflines, which is due to the moisture loads being driven in and out of the foam by radiant solar heating and night cooling. The moisture levels in the sealed attics at all six sites showed similar daily moisture levels throughout the year. Under the current regime of operation the HPWH does not appear to remove enough moisture each day to make significant reductions in daily peak moisture loads compared to the adjacent house with a standard ERSWH. Further monitoring and research are needed to better understand this effect and to develop strategies that effectively reduce moisture levels in sealed attics of low-load homes. One potential HPWH operating regime would be to significantly increase the tank set point temperature in the mornings. 


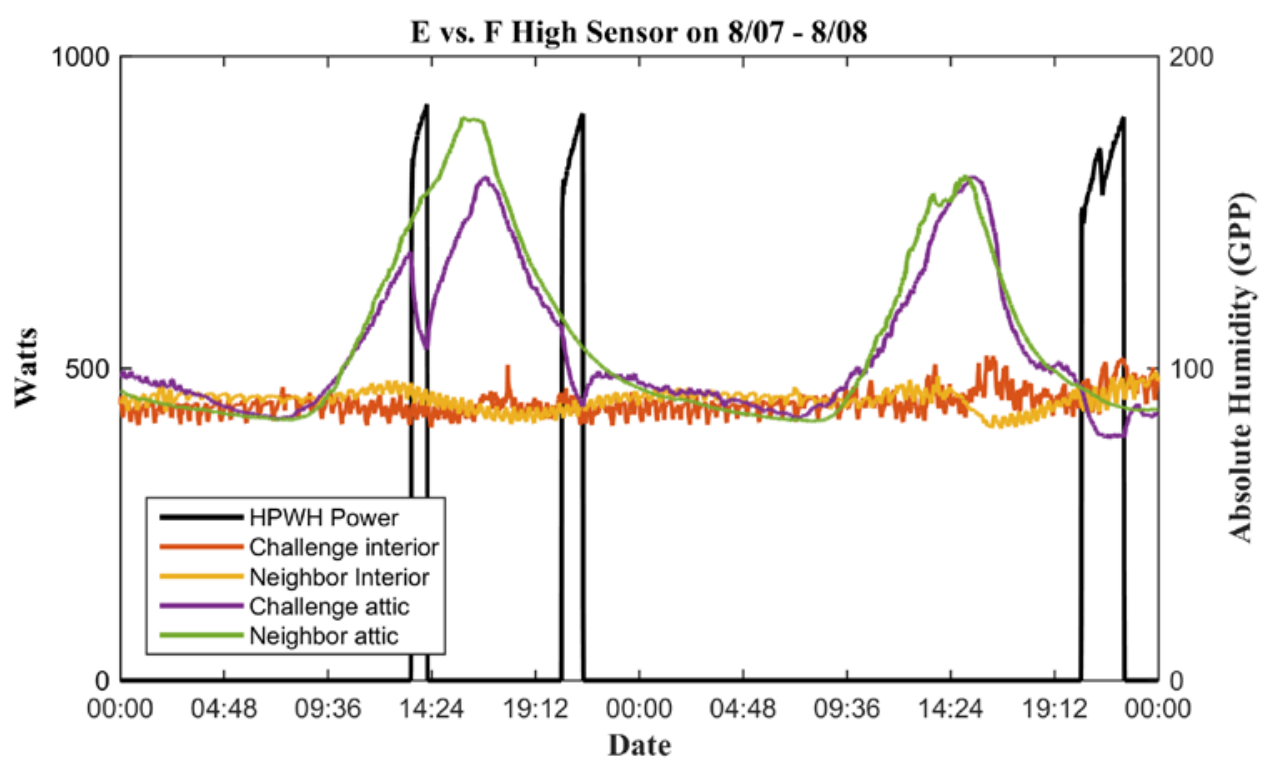

Figure 23. Savannah Unit $E$ and $F$ absolute humidities at the high center location of the attic and of the living space

The attic temperatures were monitored in four locations (north, south, and east sides of the house and high center of the attic about $6 \mathrm{ft}$ from the attic floor, Figure 24). The temperatures decreased when the HPWH operated at the end of the day, but it is difficult to distinguish the cause between HPWH operation and the sun setting. During the first half of the day attic temperatures increased when the sun rose. In one instance, the HPWH operated during the first half of the day and the east side decreased by less than $2^{\circ} \mathrm{F}$, which is where the duct pointed. The north and south sensors decreased by less than $0.4^{\circ} \mathrm{F}$. The sensor at the high center of the attic continued to increase while the HPWH operated. Figure 25 shows a zoomed image of the temperatures during this time. Because the HPWH could reduce the attic temperature in only one area of the attic, the HPWH most likely had no impact on the temperature in the living zone or on the energy consumed by the HVAC equipment.

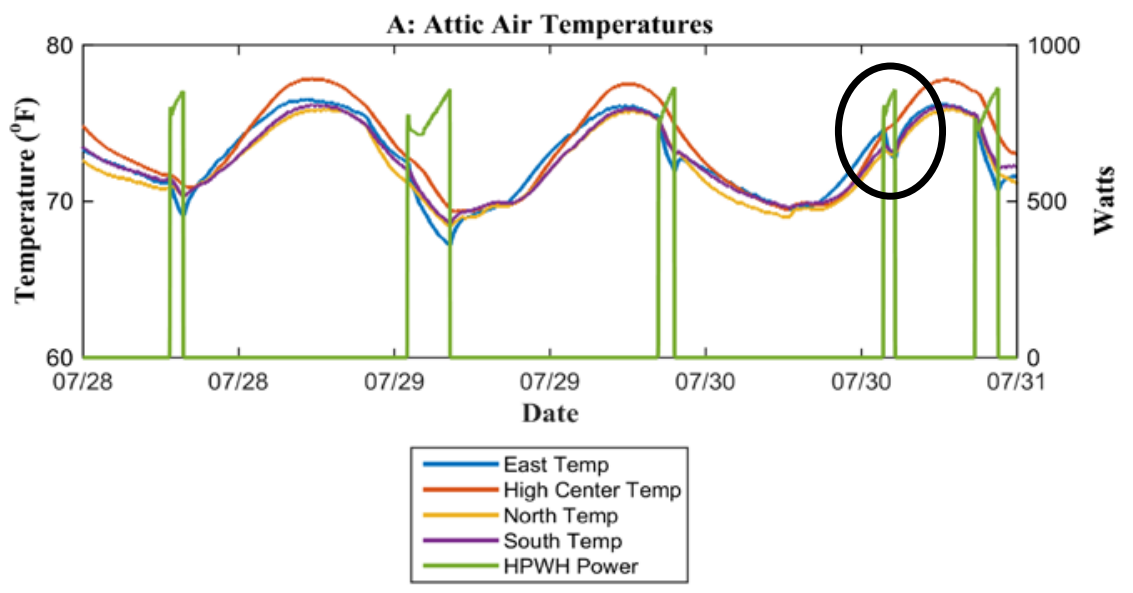

Figure 24. Attic temperatures at five locations around the attic during the summer at Site $A$. The circled area can be seen in zoom in Figure 25. 


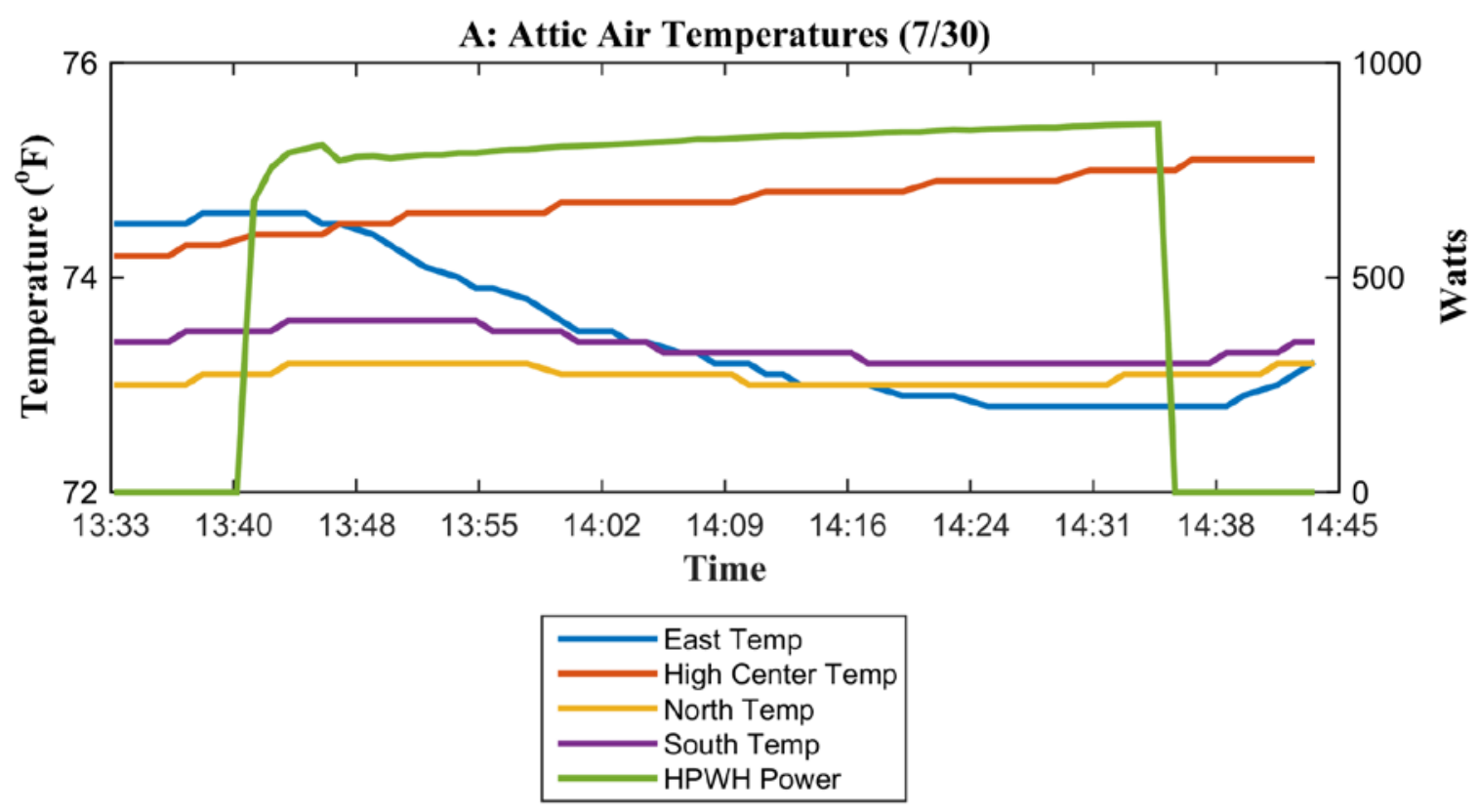

Figure 25. Zoomed section of Figure 24 showing attic temperature changes during HPWH operation

\subsection{Effect of Incoming Air Temperature}

Figure 26 plots the daily COP values as a function of the daily DHW consumption and the intake air across the evaporator coil. Previous field monitoring and laboratory studies have shown that intake air wet bulb temperature across the evaporator coil improved COP as energy transfer is more effective at greater $\Delta \mathrm{Ts}$ between the ambient air and evaporator coil (Shapiro and Puttagunta 2013; Sparn et al. 2011). This trend is not evident in the data. However, the highest measured COP occurred in the warmer and more humid attic in Savannah. These results can be attributed to:

- Units in LaFayette likely experienced some recirculation because the relief vent at the bottom of the exhaust duct kit effectively cooled the mechanical closet. Mechanical closets would warm if the HPWH did not run, which means fewer water draws occurred.

- The chart is predominantly colored in the blue range, which means the intake air temperature varied only slightly, and no trend in color pattern emerges. A larger sample size with more variation would be needed to verify the trend of increased COP values with increased intake temperature. 


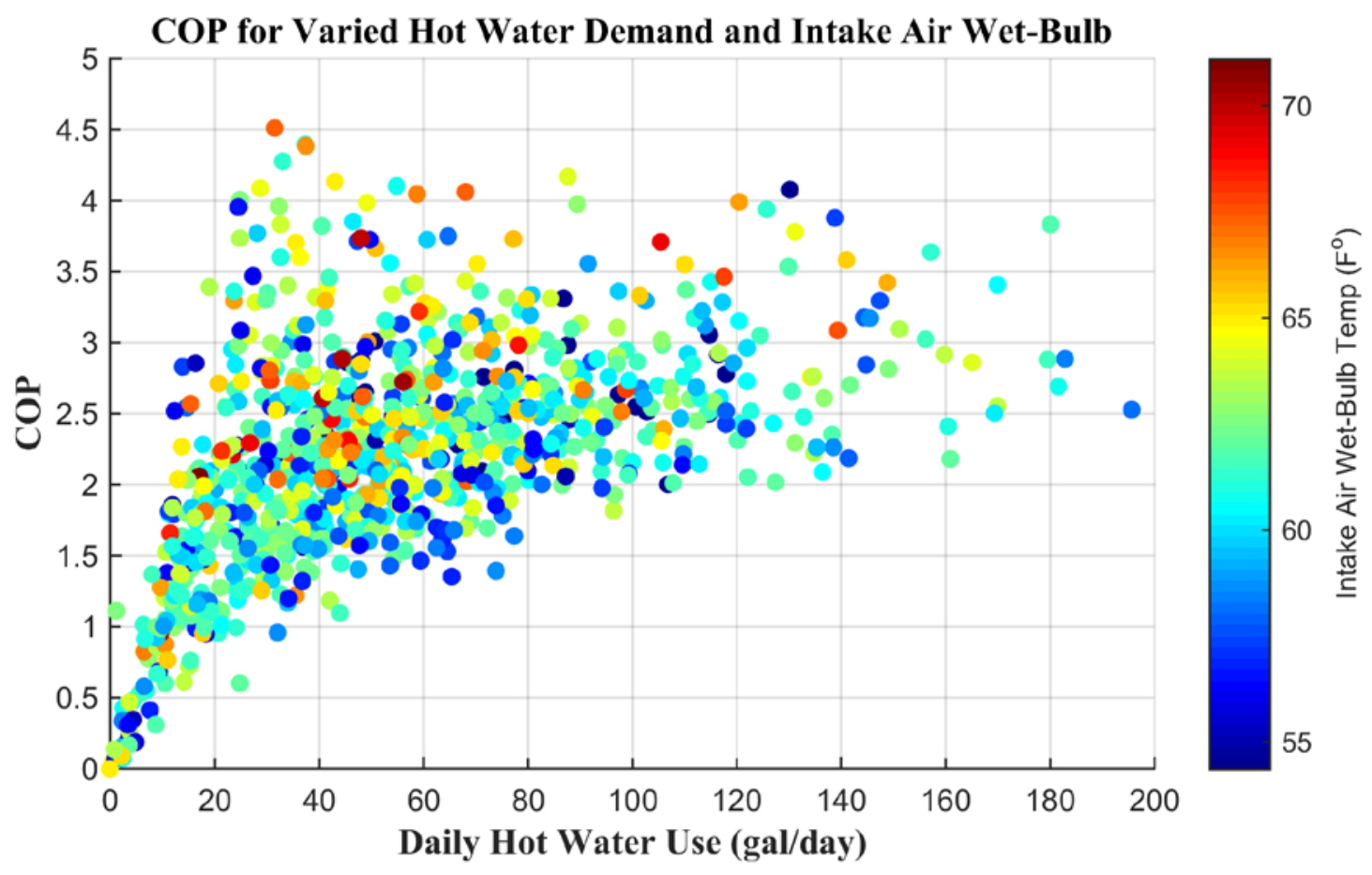

Figure 26. COP as a function of daily DHW consumption and intake air wet bulb temperature

Table 10 reports the average air intake and exhaust temperatures and absolute humidities across the evaporator coil during heat pump operation at each monitored site. Unit E1 (set point of $120^{\circ} \mathrm{F}$ ) had the highest average intake air temperature and humidity, which resulted in the highest average daily COP of 3.1. The change in the intake airstream's temperature and humidity were significantly reduced when the set point was adjusted to $150^{\circ} \mathrm{F}(\mathrm{E} 2)$, which lowered the COP to 1.9. This was likely due to increased HPWH operating duration. This shows that increased HPWH runtimes will have a greater impact on attic air temperatures; however, the attic temperatures promptly return to preoperating conditions when the HPWH stops. Unit $\mathrm{C}$ had the greatest decrease in temperature and humidity across the coil. Coincidentally, Unit $\mathrm{C}$ also had the third-greatest average daily DHW demand.

Table 10. Average Intake and Exhaust Air Temperatures and Absolute Humidities, Measured In Grains per Pound, across the Heat Pump during Operation

\begin{tabular}{|c|c|c|c|c|c|c|c|c|}
\hline$\stackrel{\mathscr{n}}{n}$ & 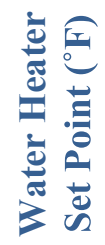 & 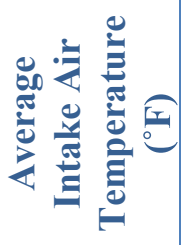 & 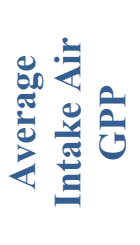 & 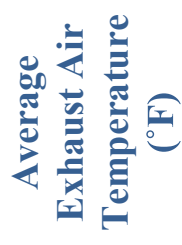 & 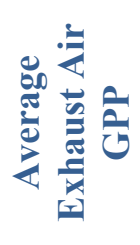 & 与 & 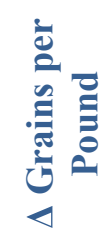 & 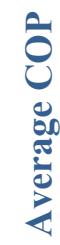 \\
\hline $\mathbf{A}$ & 120 & 69.0 & 67.8 & 50.6 & 41.4 & -18.4 & -26.4 & 2.6 \\
\hline B & 120 & 70.0 & 67.3 & 57.3 & 48.6 & -12.7 & -18.7 & 2.0 \\
\hline C & 120 & 71.6 & 66.1 & 48.7 & 39.2 & -22.9 & -26.9 & 2.4 \\
\hline D & 120 & 69.3 & 67.1 & 51.5 & 42.5 & -17.8 & -24.6 & 2.2 \\
\hline E1 & 120 & 79.3 & 75.4 & 60.4 & 65.1 & -18.9 & -10.3 & 3.0 \\
\hline E2 & 150 & 74.1 & 64.2 & 58.8 & 59.7 & -15.3 & -4.5 & 1.9 \\
\hline
\end{tabular}




\subsection{Error Induced by Measurement Instrumentation}

The inlet and outlet temperatures measured by the Badger In-line Btu meters were housed in heavy brass couplings (Figure 27), which affected the temperature readings because their thermal mass was in contact with the thermocouples. The heavy mass caused temperature readings to skew toward ambient air temperatures. Once this profound effect was noticed, the metal couplings were insulated (Figure 28). When a DHW draw occurred, the outlet water temperature reading took about 2 min to reach the maximum measured temperature (Figure 29), which still was cooler than the tank set point.

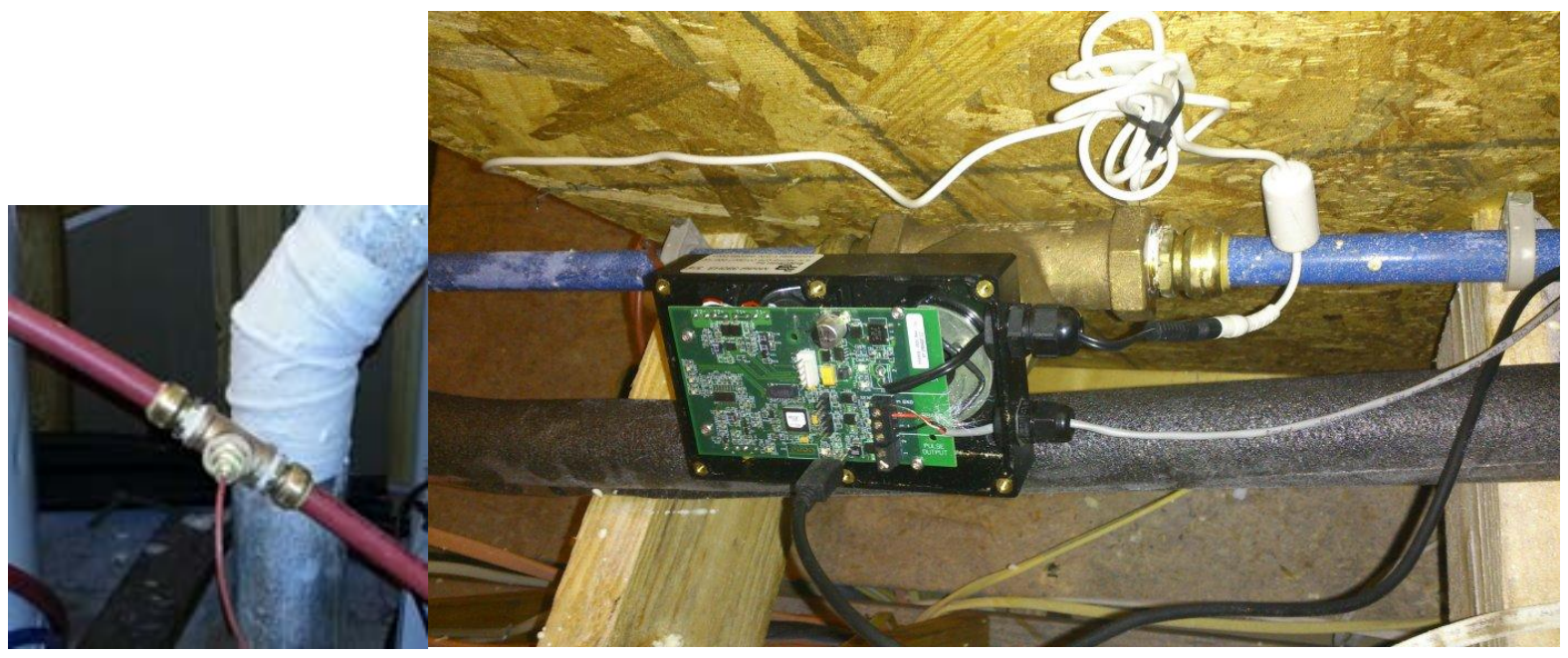

Figure 27. Brass fittings housing the thermocouples measuring outlet (left); inlet water temperatures and flow rate before being insulated (right)
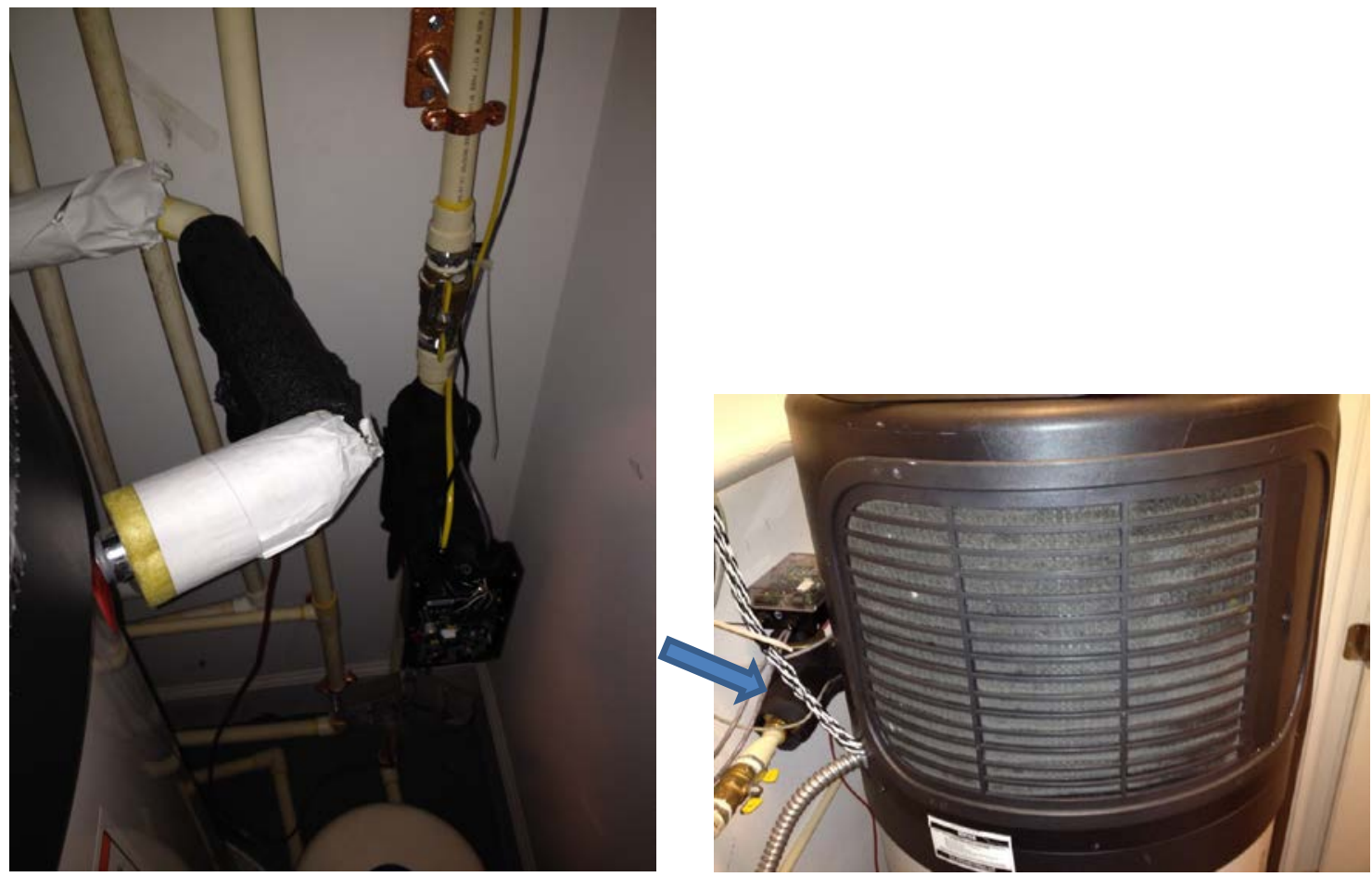

Figure 28. Images of an insulated water meter and thermocouple brass fittings at the LaFayette site; front grille/filter showing obvious signs of debris (right) 


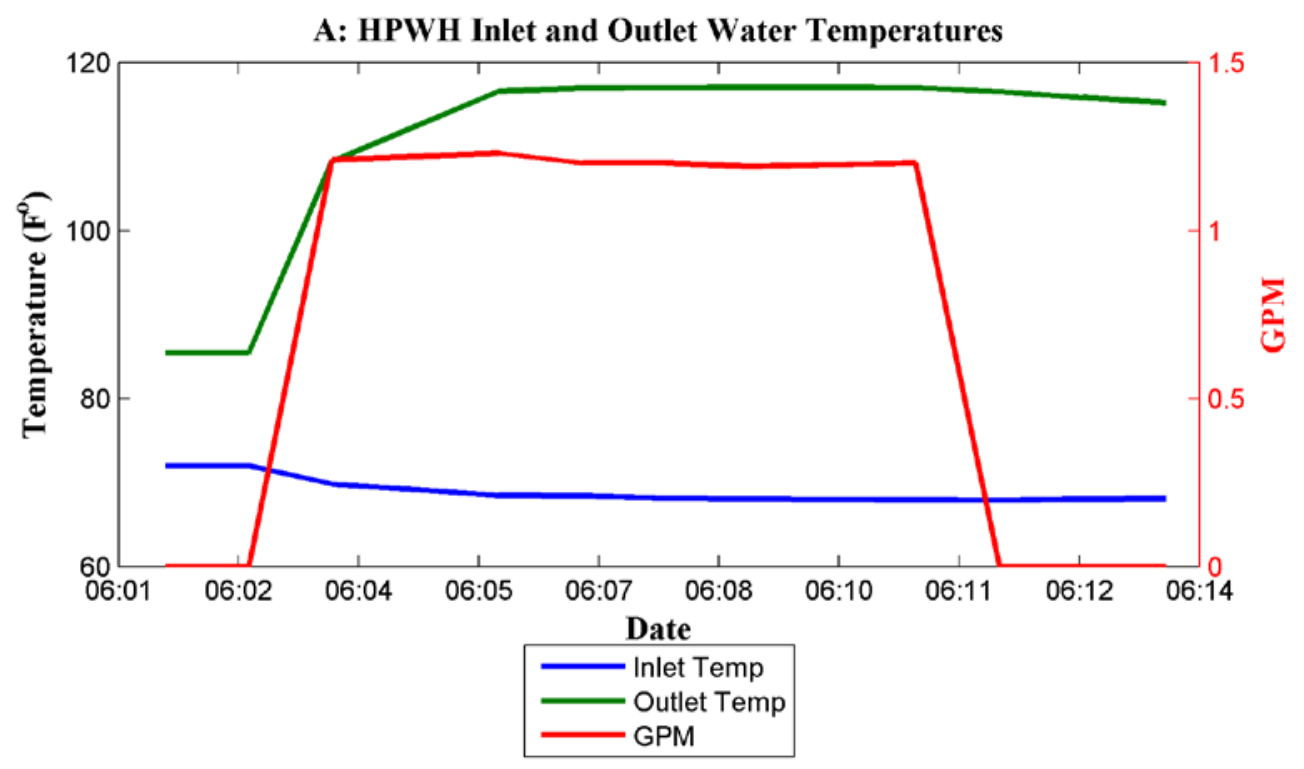

Figure 29. Effect of Badger Meter's thermal mass on water temperature measurements

Daily average hot water outlet temperatures during draws for each site are characterized by histograms in Figure 30 . When the tank set point was known to be $120^{\circ} \mathrm{F}$, the daily average measured hot water outlet temperature was approximately $110^{\circ} \mathrm{F}$ for all units. E2 had a tank set point temperature of $150^{\circ} \mathrm{F}$, and the daily average measured hot water outlet temperature was $128^{\circ} \mathrm{F}$. The daily hot water outlet temperature approched the set point temperature when hot water draws were sustained for long enough periods of time to overcome the thermal mass of the brass thermocouple housings. Average daily outlet temperature occurences lower than $100^{\circ} \mathrm{F}$ are attibuted to days when the maximum draw duration was less than 2 min.

COP calculations used inlet/outlet water temperatures during DHW draws when the measured temperatures were adversely affected by the sensor housing's thermal mass. Most draws were less than or equal to $2 \mathrm{~min}$ (Table 11). However, most draw volumes were during events that were longer than $2 \mathrm{~min}$. This systemic measurement error would tend to propagate through the analysis and result in reducing the calculated values of COP below actual performance. 


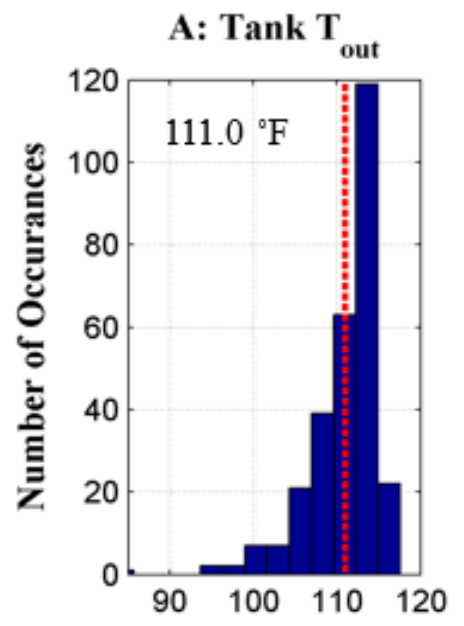

Temperature $\left(\mathbf{F}^{0}\right)$

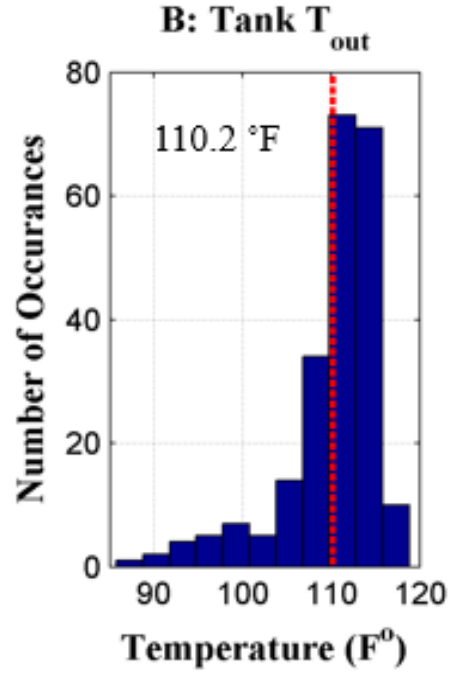

E1: Tank $\mathbf{T}_{\text {out }}$

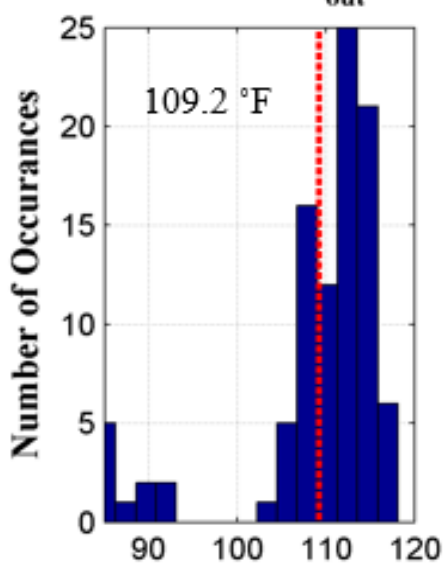

Temperature $\left(\mathbf{F}^{0}\right)$

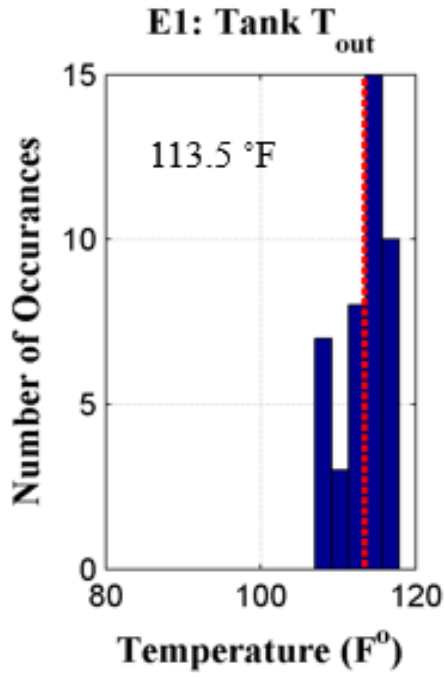

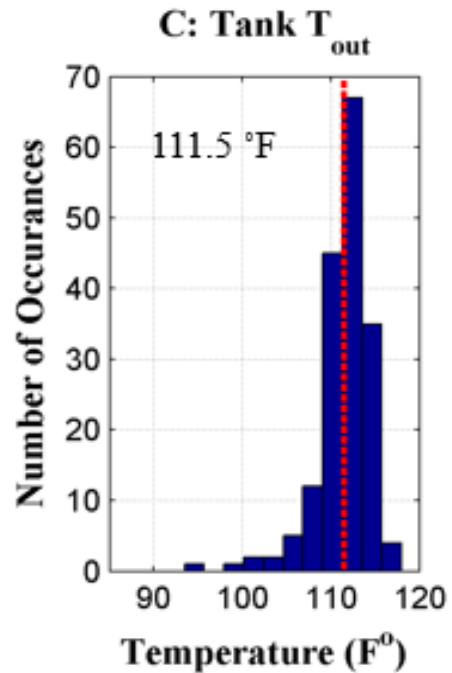

E2: Tank $\mathbf{T}_{\text {out }}$

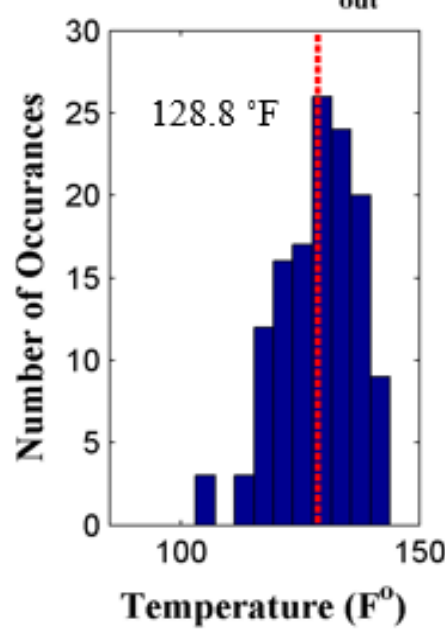

Figure 30. Histograms of daily average hot water temperatures measured leaving the tank during draw periods. Number of occurrences equals number of days.

Table 11. Statistics of Number of Occurrences of Short DHW Draw Durations

\begin{tabular}{c|c|c|c|c|c|c}
\hline Site & $\begin{array}{c}\text { Average } \\
\text { HW } \\
\text { Draw } \\
\text { Time }\end{array}$ & $\begin{array}{c}\text { \# of 1- } \\
\text { Min } \\
\text { Events }\end{array}$ & $\begin{array}{c}\text { \# of 2- } \\
\text { Min } \\
\text { Events }\end{array}$ & $\begin{array}{c}\text { \# of }>\text { 2- } \\
\text { Min } \\
\text { Events }\end{array}$ & $\begin{array}{c}\text { Percent } \\
\text { of Draws } \\
\text { S2 Min }\end{array}$ & $\begin{array}{c}\text { Percent of Total } \\
\text { Volume Draw } \\
\text { during } \leq 2-M i n \\
\text { Draw Periods }\end{array}$ \\
\hline A & 5.3 & 1,423 & 545 & 1,030 & $65.6 \%$ & $15.3 \%$ \\
B & 2.9 & 1,036 & 445 & 537 & $73.4 \%$ & $33.9 \%$ \\
C & 3.3 & 1,148 & 555 & 918 & $65.0 \%$ & $22.3 \%$ \\
D & 2.8 & 722 & 334 & 352 & $75.0 \%$ & $33.7 \%$ \\
E1 & 2.4 & 601 & 97 & 267 & $72.3 \%$ & $21.2 \%$ \\
E2 & 1.9 & 2,842 & 312 & 615 & $83.7 \%$ & $35.7 \%$ \\
\hline
\end{tabular}


Despite the adverse impact of the water temperature measurements, the COP value measured in Savannah, Georgia, with a $120^{\circ} \mathrm{F}$ set point is the highest known value for A.O. Smith Voltex HPWH realized in a field monitoring study.

\subsection{LaFayette Survey Results}

Southface wrote a survey that LHA issued to the tenants of all 30 duplexes with ducted HPWHs to assess their satisfaction about DHW demand. Figure 32 through Figure 34 represent the survey results vis-à-vis the occupants' satisfaction with their hot water supply.

More than half the respondents indicated that they plan their shower timing to avoid running out of hot water (Figure 31). However, more than $70 \%$ have either never or seldom experienced a shortage of hot water while showering or bathing (Figure 32). These data do not show whether the respondents' behavior in timing showers is due to experiences in the LaFayette homes or is learned behavior from past experiences, especially because they have lived in these homes for less than 1 year. Hot water shortages were predominately during showers, because $80 \%$ reported never running out of hot water while using the kitchen sink.

\section{Avoid Consecutive Showers}

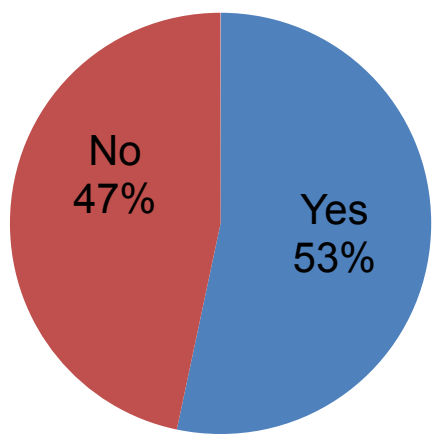

Figure 31. Do you avoid taking consecutive showers to prevent running out of hot water?

\section{Experience Shortage of Hot Water while Showering or Bathing}

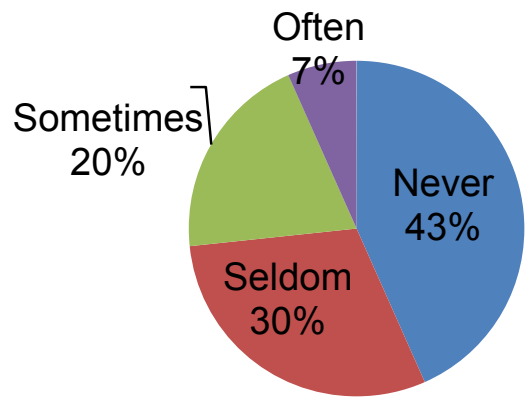

Figure 32. How often, if ever, do you experience a shortage of hot water while showering or bathing? 


\section{Experience Shortage of Hot Water Using Kitchen Sink}

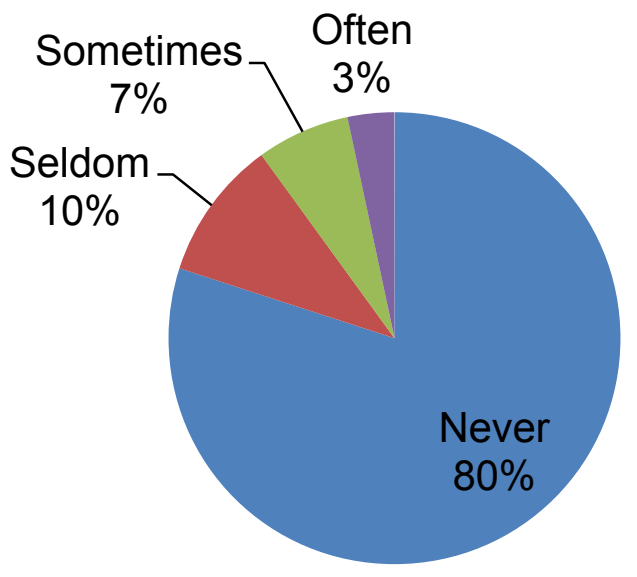

Figure 33. How often, if ever, do you experience a shortage of hot water while using the kitchen sink?

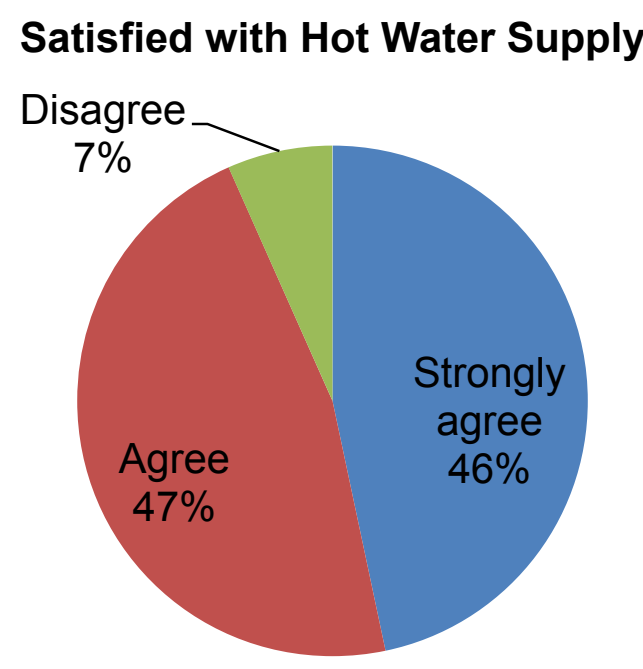

Figure 34. I am satisfied with the supply of hot water in my home.

In regards to overall satisfaction, 93\% reported they agreed or strongly agreed they experience satisfactory hot water supply. LHA reported that it has not received any direct complaints about shortages of hot water. LHA does not intend to adjust the tank set point temperature beyond $120^{\circ} \mathrm{F}$ or switch HPWH operation into hybrid mode, because the current settings appear to satisfy the tenants.

Previous research has identified HPWH operation noise as a barrier to acceptance of installation inside the living space, such as in the utility closets in the LaFayette community (Chasar and Martin 2013). This was one factor that led the research team to recommend a solid door on the utility closet and ducting of the HPWH to and from the encapsulated attic. Both the HPWH and 
the HVAC air handler were located inside different closets inside the living space. The resident survey asked several questions to help identify whether this particular installation, which runs $100 \%$ in heat pump mode, has any negative noise impact.

\section{Noise from behind Locked Doors}

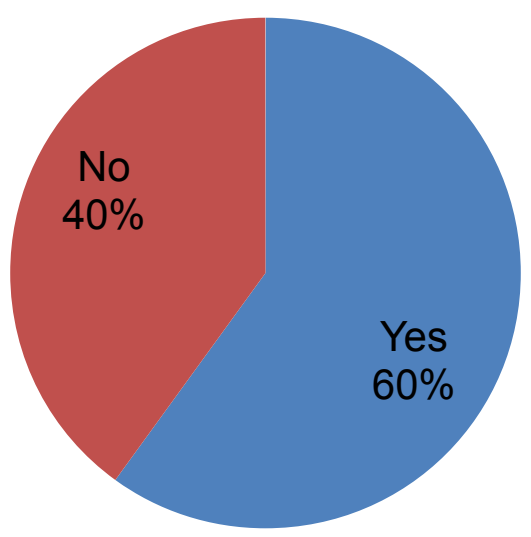

Figure 35. Do you hear noise from the mechanical equipment behind the locked doors in your home?

\section{Frequently Hear Mechanical Equipment}

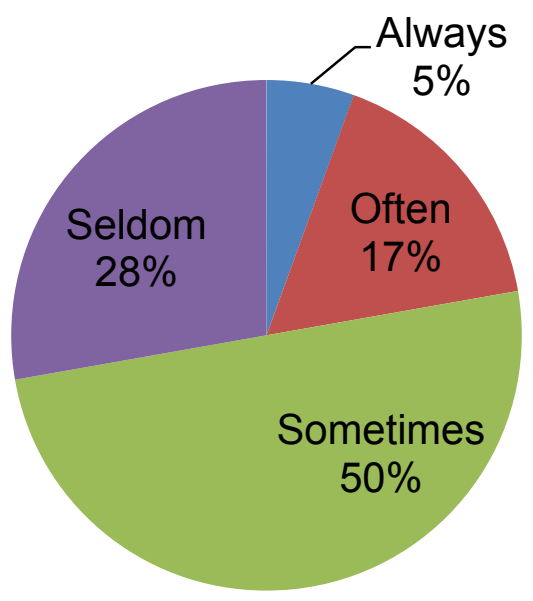

Figure 36. How often do you hear the operation of mechanical equipment behind the locked doors in your home? 


\section{Noise Is Disturbing Daily Activities}

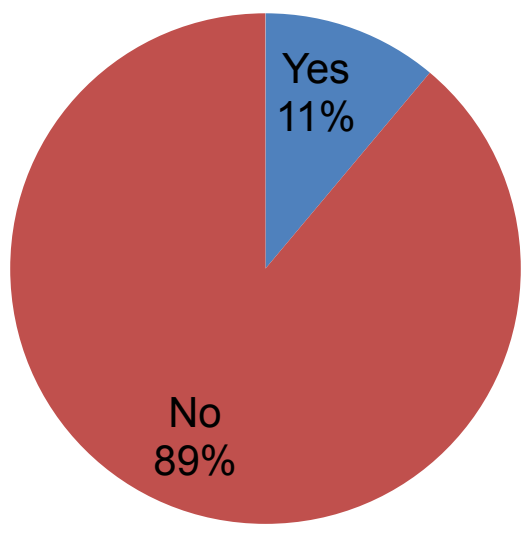

Figure 37. Does the noise disturb your daily activities? If yes, please explain.

Examination of more detailed questions allowed the researchers to identify that, of the 18 residents who indicated they have heard noise from the utility closet, 11 were related to the HPWH, four to the air handling unit, and three could be either. Even though 18 residents reported hearing noise, only two indicated it disturbed their daily activities. LHA has reported that it has not received complaints from residents and does not plan to make changes to HPWH operation based on noise. 


\section{Conclusions}

The effect of ducting an HPWH's supply or exhaust airstream does not diminish its efficiency if supply-side ducting does not reduce intake air temperature, which expands HPWH application to confined areas. Exhaust ducts should be insulated to avoid condensation on the exterior; however, this increases the risk of condensation in the duct's interior near the HPWH, because the temperatures vary greatly between the compressor and the duct and standing bulk water around the condenser. All ducts should be at least 8 in. in diameter to prevent airflow restriction for A.O. Smith Voltex (PHPT-60/80) HPWHs. The ducted HPWH's air-conditioning impact on HVAC equipment loads appears to be minimal when it is connected to an attic and not the living zone, because attic temperatures are impacted only during HPWH operation and immediately return to normal levels after the HPWH stops. An HPWH is not suitable as a replacement dehumidifier under normal operation in sealed attics, because peak moisture loads decreased only if the heat pump operated during the morning.

Do HPWHs installed in or connected to encapsulated attics perform differently in different climate zones?

- HPWHs installed in or connected to encapsulated attics appear to perform better in Climate Zone 2 than in Climate Zone 4 because of increased attic air temperature and humidity. The heat pump intake air temperature and humidity appear to be the dominant variables that affect HPWH performance.

How do the real-world COPs vary when they are subjected to different use patterns, and how do they compare to other field studies?

- HPWH COP values are dependent on several variables, including intake air temperature and humidity, inlet water temperature, number of heat pump operation events, total DHW demand, DHW demand during a heat pump operation event, and tank set point temperature. Because of this complexity, strong correlations between COP and any single variable were not necessarily established. The values calculated in this study are similar to other field-monitoring studies and laboratory studies of unducted HPWHs.

Did the HPWH satisfy DHW demand in the efficiency operating mode?

- The HPWH satisfied DHW demand in the efficiency operating mode, because no complaints were reported to LHA or from the homeowner in Savannah. A survey was administered to the residents in 30 duplex units in LaFayette, and $93 \%$ of the tenants agreed that they had satisfactory DHW supply. However, the homeowner in Savannah increased the tank set point temperature to $150^{\circ}$ from $120^{\circ} \mathrm{F}$, but not necessarily due to unsatisfactory supply from the HPWH in efficiency mode - it was turned off for a long period before. The increased set point reduced the COP from 3.1 to 2.0 and the total DHW consumption by $21.1 \mathrm{gal} /$ day.

How much does HPWH exhaust air affect temperature and RH conditions in the mechanical closet and attic space compared to alternative systems? 
- The air conditioning provided by the HPWH affects the temperature of the mechanical closet and attic space only during the time the heat pump is operating. Shortly after the heat pump stops operating, the values return to previous levels. Encapsulated attic peak humidity levels can be reduced if the heat pump operates during the first half of the day compared to when it operates later in the day or compared to an alternative DHW system.

Do different HPWH ducting strategies affect whole-house heating, cooling, and moisture loads?

- Different HPWH ducting strategies did not have a major impact on whole-house heating, cooling, and moisture loads. The attic temperatures decreased during operation of the HPWH but returned to their preoperating condition within a few minutes after the HPWH stopped. The air conditioning of the HPWH did not appear to have any effect on the living zone air conditions.

Do different HPWH ducting strategies affect HPWH performance?

- Different ducting strategies had no impact on COP. The intake air temperature increased slightly but not enough to increase COP.

How well does BEopt account for the interaction between the HPWH and total space-heating, cooling, and moisture loads?

- BEopt shows that the HPWH slightly decreased the cooling site energy consumption of the three models by $59 \mathrm{kWh} / \mathrm{yr}(10 \%), 70 \mathrm{kWh} / \mathrm{yr}(9 \%)$, and $97 \mathrm{kWh} / \mathrm{yr}(11 \%)$, respectively, for the two-bedroom and three-bedroom LaFayette models and the home in Savannah. The heating site energy consumption increased by $123 \mathrm{kWh} / \mathrm{yr}(11 \%), 147$ $\mathrm{kWh} / \mathrm{yr}(11 \%)$, and $88 \mathrm{kWh} / \mathrm{yr}(11 \%)$, respectively, to compensate for the HPWH cooling air during the heating season. The attic temperatures measured during HPWH operation regularly decreased only if the sun was setting and the temperatures were already decreasing. If the sun was rising, causing attic temperatures to increase, HPWH operation would not necessarily decrease the attic temperature. This leaves some doubt about whether the HPWH will impact space-conditioning loads. 


\section{References}

A.O. Smith. (2011a). Ducting Kit Installation Instruction for Hybrid Electric Heat Pump Water Heaters. Retrieved from http://www.hotwater.com/Resources/Literature/InstructionManuals/Residential-Electric/HPWH-Inlet/Outlet-Duct-Instructions-(323471)/

A.O. Smith. (2011b). Service Handbook-Residential Hybrid Electric Heat Pump Water Heater for Models: PHPT-60 and PHPT-80. Ashland City, TN.

A.O. Smith. (2012). Installation Instructions and Use \& Care Guide.

Amarnath, A., \& Bush, J. (2012). Heat Pump Water Heaters: Field Evaluation of New Residential Products (pp. 24-36). ACEEE Summer Study on Energy Efficiency in Buildings. Retrieved from http://www.aceee.org/files/proceedings/2012/data/papers/0193-000013.pdf

Chasar, D., \& Martin, E. (2013). Efficient Multifamily Homes in a Hot-Humid Climate by Atlantic Housing Partners.

Community Housing Services Agency Inc. (2012). Savannah Gardens. Retrieved from http://chsadevelopment.org/

Ecotope Inc, \& Northwest Energy Efficiency Alliance. (2015). Heat Pump Water Heater Model Validation Study.

Engebrecht Metzger, C., Wilson, E., \& Horowitz, S. (2012). Addendum to the Building America House Simulation Protocols. Golden, CO. Retrieved from

http://www.nrel.gov/docs/fy13osti/57450.pdf

Hendron, R., \& Engebrecht, C. (2010). Building America House Simulation Protocols. Golden, CO. Retrieved from http://www.nrel.gov/docs/fy11osti/49246.pdf

Larson, B., \& Bedney, K. (2011). Interim Report and Preliminary Assessment of AO Smith Voltex PHPT-80 Hybrid Heat Pump Water Heater. Bonneville Power Administration.

Shapiro, C., \& Puttagunta, S. (2013). Field Performance of Heat Pump Water Heaters in the Northeast. Retrieved from http://www.carb-swa.com/Collateral/Documents/CARBSWA/Research/58115_sw 2013-08-07.pdf

Sparn, B., Earle, L., Christensen, D., Maguire, J., Wilson, E., \& Hancock, C. E. (2013). Field Monitoring Protocol : Heat Pump Water Heaters.

Sparn, B., Hudon, K., \& Christensen, D. (2011). Laboratory performance evaluation of residential integrated heat pump water heaters. Contract. Retrieved from http://www.nrel.gov/docs/fy11osti/52635.pdf

Wilson, E., Engebrecht Metzger, C., Horowitz, S., \& Hendron, R. (2013). Building America House Simulation Protocols. Golden,CO. 


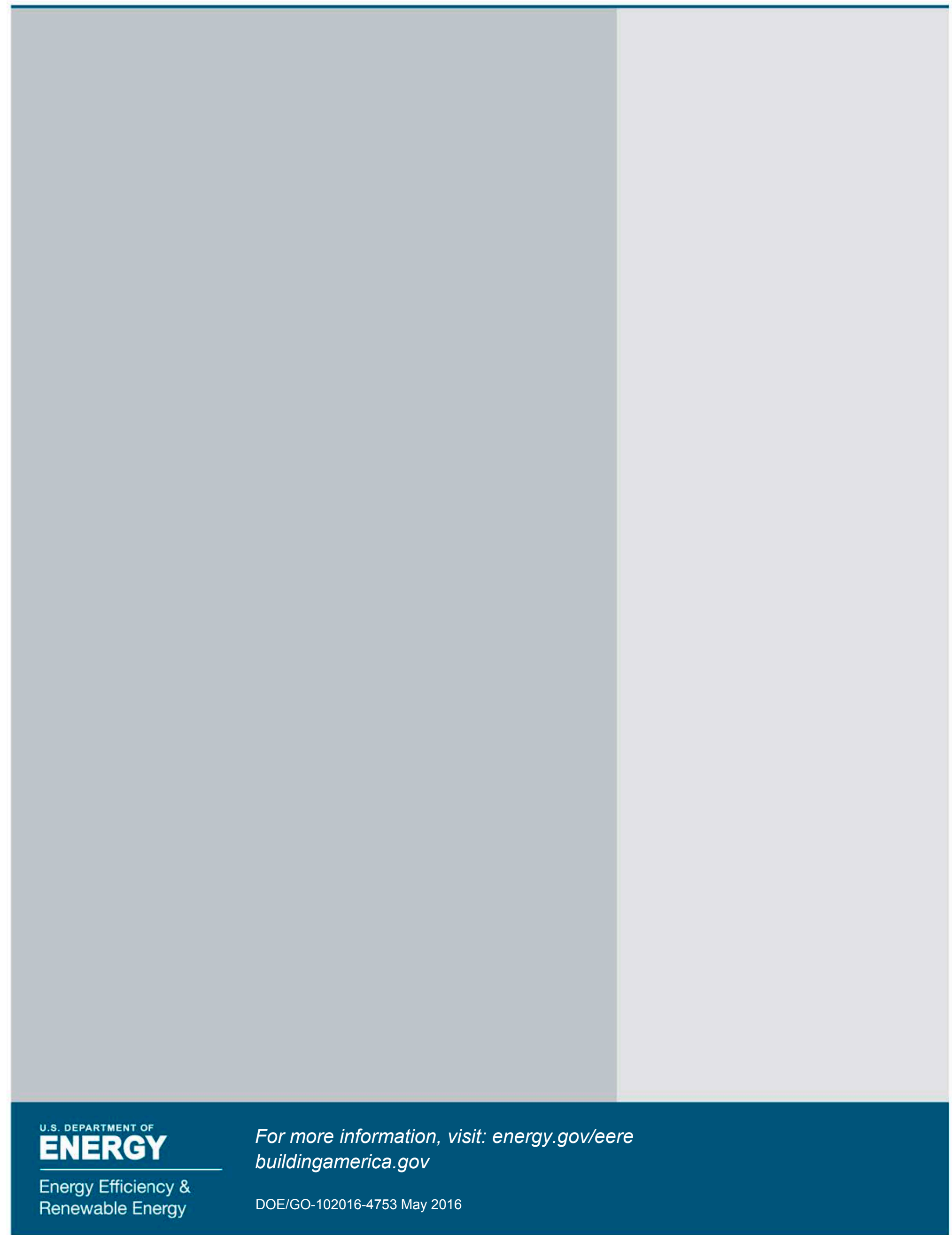

